Supporting Information

\title{
Tuning Second Coordination Sphere Interactions in Polypyridyl-Iron Complexes to Achieve Selective Electrocatalytic Reduction of Carbon Dioxide to Carbon Monoxide
}

\author{
David Z. Zee, $\uparrow^{1,6}$ Michael Nippe, $\$^{1,6,7}$ Amanda E. King, ${ }^{1}$ \\ Christopher J. Chang* 1,2,4 and Jeffrey R. Long*1,3,5,6
}

Departments of ${ }^{1}$ Chemistry, ${ }^{2}$ Molecular and Cell Biology, ${ }^{3}$ Chemical and Biomolecular Engineering, University of California, Berkeley, Berkeley, California 94720, United States

${ }^{4}$ Chemical Sciences Division, ${ }^{5}$ Materials Sciences Division, and the ${ }^{6}$ Joint Center for Artificial Photosynthesis, Lawrence Berkeley National Laboratory, Berkeley, California 94720 , United States

${ }^{7}$ Department of Chemistry, Texas A\&M University, 3255 TAMU, College Station, Texas 77843, United States

†Present address: Northwestern University, 2145 Sheridan Road, Evanston IL 60208.

fD.Z.Z. and M.N. contributed equally to this work.

*E-mail: chrischang@berkeley.edu (C.J.C.), jrlong@berkeley.edu (J.R.L.) 


\section{Table of Contents}

Syntheses of Ligands S3

Scheme S1. Synthetic scheme for the ligands bpy ${ }^{\mathrm{OMe}} \mathrm{PY2Me}$, bpy ${ }^{\mathrm{OH}} \mathrm{PY} 2 \mathrm{Me}$, bpy ${ }^{\text {NHEtPY2Me, }}$

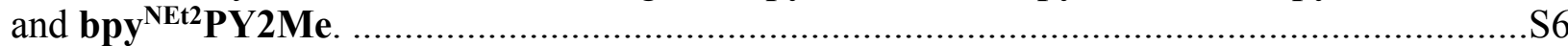

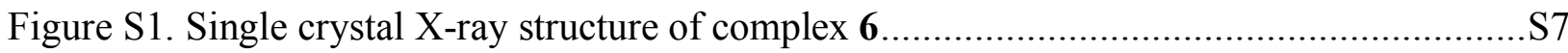

Table S1. Crystallographic data for complexes 2 - 6 .....................................................S8-9

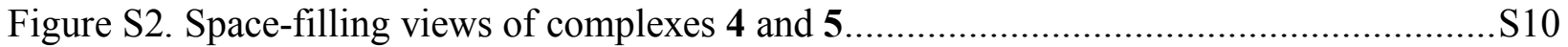

Table S2. Highlighted crystallographic bond distances for complexes 1-6 .............................S1

Figures S3-S8. CVs in acetonitrile with variable scan rate ........................................... S12-17

Figures S9-S13. UV-vis spectra of Fe complexes in acetnitrile-water...............................S18-20

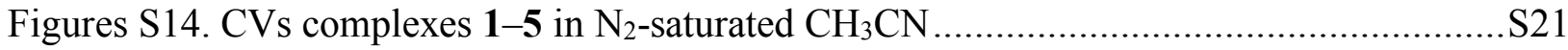

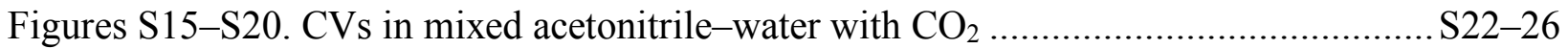

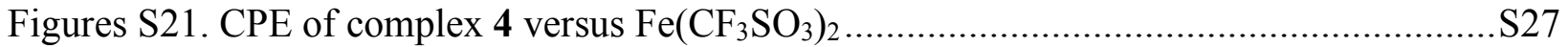

Table S3. Controlled-potential electrolyses data without background corrections .....................S27

Table S4. Controlled-potential electrolyses data with background corrections ..........................S28

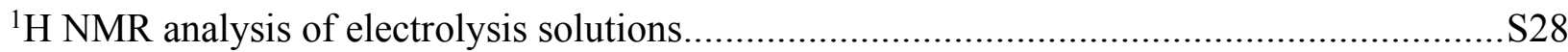

Table S5. Faradaic efficiencies of Fe-containing electrocatalysts for $\mathrm{CO}_{2}$ reduction................S29

Figure S22. Electrochemical characterization of electrode postelectrolysis..............................S30

Figure S23. SEM and EDX analysis of electrode postelectrolysis...........................................S31

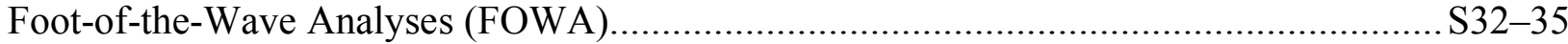

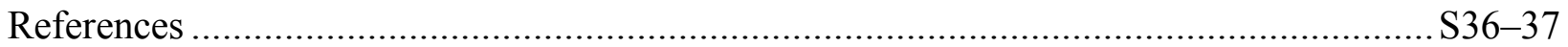




\section{Syntheses of Ligands}

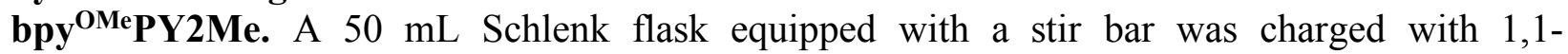
bis(pyridyl)ethane $(1.81 \mathrm{~g}, 9.80 \mathrm{mmol})$ and $50 \mathrm{~mL}$ of THF, then cooled to $-78{ }^{\circ} \mathrm{C}$. The solution was vigorously stirred while ${ }^{\mathrm{n}} \mathrm{BuLi}(2.5 \mathrm{M}$ in hexanes, $3.9 \mathrm{~mL}, 9.8 \mathrm{mmol})$ was added via syringe in a dropwise fashion. The resulting dark red solution was allowed to stir at $-78{ }^{\circ} \mathrm{C}$ for $1 \mathrm{~h}$, after which a solution of 6-fluoro-6'-methoxy-2,2'-bipyridine $(1.00 \mathrm{~g}, 4.90 \mathrm{mmol})$ in $10 \mathrm{~mL}$ of THF was introduced using a cannula. After the transfer was complete, the reaction was refluxed for $12 \mathrm{~h}$. The reaction was quenched with $100 \mathrm{~mL}$ of saturated aqueous $\mathrm{NH}_{4} \mathrm{Cl}$, and the workup was performed in air. The aqueous phase was separated and extracted with $4 \times 50 \mathrm{~mL}$ of EtOAc. The organics were combined, dried over $\mathrm{MgSO}_{4}$, filtered, and concentrated yielding a brown oil by rotary evaporation. Flash chromatography (silica, 3:1 to $1: 1$ hexanes:EtOAc, $\mathrm{R}_{\mathrm{f}}=0.29$ in $1: 1$ hexanes:EtOAc) followed by recrystallization from hot $\mathrm{Et}_{2} \mathrm{O}$ afforded the product as colorless crystals $(2.67 \mathrm{~g}, 74 \%)$. ${ }^{1} \mathrm{H}$ NMR $\left(500 \mathrm{MHz}, \mathrm{CDCl}_{3}\right) \delta 8.60$ (ddd, $\left.J=4.9,2.0,0.9 \mathrm{~Hz}, 2 \mathrm{H}\right), 8.25$ $(\mathrm{dd}, J=7.8,1.0 \mathrm{~Hz}, 1 \mathrm{H}), 7.79(\mathrm{dd}, J=7.5,0.9 \mathrm{~Hz}, 1 \mathrm{H}), 7.71(\mathrm{t}, J=7.8 \mathrm{~Hz}, 1 \mathrm{H}), 7.62-7.53(\mathrm{~m}$, $3 \mathrm{H}), 7.17-7.07(\mathrm{~m}, 5 \mathrm{H}), 6.71(\mathrm{dd}, J=8.2,0.8 \mathrm{~Hz}, 1 \mathrm{H}), 4.02(\mathrm{~s}, 3 \mathrm{H}), 2.41(\mathrm{~s}, 3 \mathrm{H}) .{ }^{13} \mathrm{C} \mathrm{NMR}(126$ $\left.\mathrm{MHz}, \mathrm{CDCl}_{3}\right) \delta 166.4,164.8,163.5,154.7,154.0,148.9,139.3,136.9,135.9,123.8,123.5,121.3$, $118.4,114.1,110.8,60.5,53.3,27.4$. ESI-MS $m / z$ for $[\mathrm{M}+\mathrm{H}]^{+}$requires 369.1710 , found 369.1732 . Anal. Calcd. for $\mathrm{C}_{23} \mathrm{H}_{20} \mathrm{~N}_{4} \mathrm{O}$ : C, 74.98; H, 5.47; N, 15.21. Found: C, 74.74; H, 5.58; N, 15.12.

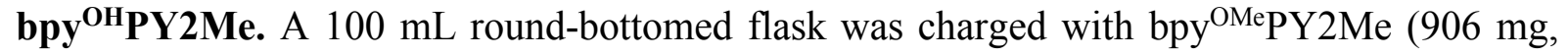
$2.47 \mathrm{mmol}), \mathrm{HBr}(12 \mathrm{~mL})$, and acetic acid $(12 \mathrm{~mL})$, then heated to reflux for $4 \mathrm{~h}$, resulting in a clear, tan-colored solution. The reaction was allowed to cool to room temperature, then quenched with excess saturated aqueous $\mathrm{NaHCO}_{3}$ solution $(100 \mathrm{~mL})$ and excess $\mathrm{Na}_{2} \mathrm{CO}_{3}$ until the $\mathrm{pH}$ reached $\sim 9$. The aqueous phase was extracted with $3 \times 100 \mathrm{~mL}$ of $\mathrm{CH}_{2} \mathrm{Cl}_{2}$. The organic extracts were combined, dried over $\mathrm{MgSO}_{4}$, filtered, and concentrated to yield a yellow oil by rotary evaporation. The oil was triturated with $\sim 30 \mathrm{~mL}$ of hexanes and dried under reduced pressure first via rotary evaporation followed by high vacuum to give an off-white, powdery solid $(828 \mathrm{mg}, 95 \%) .{ }^{1} \mathrm{H}$ NMR $\left(600 \mathrm{MHz}, \mathrm{CD}_{3} \mathrm{OD}\right) \delta 8.52(\mathrm{~d}, J=4.7 \mathrm{~Hz}, 2 \mathrm{H}), 7.96(\mathrm{~d}, J=7.9 \mathrm{~Hz}, 1 \mathrm{H}), 7.88(\mathrm{t}, J=7.9 \mathrm{~Hz}$, $1 \mathrm{H}), 7.77(\mathrm{t}, J=7.8 \mathrm{~Hz}, 2 \mathrm{H}), 7.73-7.67(\mathrm{~m}, 1 \mathrm{H}), 7.38-7.27(\mathrm{~m}, 3 \mathrm{H}), 7.18(\mathrm{~d}, J=8.1 \mathrm{~Hz}, 3 \mathrm{H})$, $6.59(\mathrm{~d}, J=9.1 \mathrm{~Hz}, 1 \mathrm{H}), 2.39$ (s, 3H). ${ }^{13} \mathrm{C} \mathrm{NMR}\left(151 \mathrm{MHz}, \mathrm{CD}_{3} \mathrm{OD}\right) \delta 166.5,166.4,165.0,149.7$, 147.7, 143.8, 143.6, 139.3, 138.2, 126.6, 125.0, 123.2, 121.3, 119.5, 106.0, 61.3, 27.6. ESI-MS $m / z$ for $[\mathrm{M}+\mathrm{H}]^{+}$requires 355.1553, found 355.1552. Anal. Calcd. for $\mathrm{C}_{22} \mathrm{H}_{18} \mathrm{~N}_{4} \mathrm{O}: \mathrm{C}, 74.56 ; \mathrm{H}$, 5.12; N, 15.81. Found: C, 74.71; H, 5.22; N, 15.43 .

2,2'-(1-(6-Bromopyridin-2-yl)ethane-1,1-diyl)dipyridine. This compound was previously prepared using a two-step, one-pot reaction starting from 2-fluoropyridine. ${ }^{1}$ A $100 \mathrm{~mL}$ Schenk flask equipped with a stir bar was charged with 1,1-bis(pyridyl)ethane (3.73 g, $20.2 \mathrm{mmol})$ and 50 $\mathrm{mL}$ of THF, then cooled to $-78^{\circ} \mathrm{C}$. The solution was vigorously stirred while ${ }^{\mathrm{n}} \mathrm{BuLi}(2.5 \mathrm{M}$ in hexanes, $8.1 \mathrm{~mL}, 20 \mathrm{mmol}$ ) was added via syringe in a dropwise fashion. The resulting dark red solution was allowed to stir at $-78^{\circ} \mathrm{C}$ for $1 \mathrm{~h}$, after which it was transferred via cannula into a solution of 2,6-dibromopyridine $(9.57 \mathrm{~g}, 40.4 \mathrm{mmol})$ in $100 \mathrm{~mL}$ of THF cooled to $-78{ }^{\circ} \mathrm{C}$. After the transfer was complete, the reaction was allowed to warm to room temperature and stirred for $24 \mathrm{~h}$. The reaction was subsequently quenched with $100 \mathrm{~mL}$ of saturated aqueous $\mathrm{NH}_{4} \mathrm{Cl}$, and the workup was performed in air. The aqueous phase was separated and extracted with $4 \times 50 \mathrm{~mL}$ of EtOAc. The organics were combined, dried over $\mathrm{MgSO}_{4}$, filtered, and concentrated to a brown oil by rotary evaporation. The product was obtained as an orange oil after flash chromatography (silica, 1:1 hexanes:EtOAc, $\left.\mathrm{R}_{\mathrm{f}}=0.25\right)$ and solvent removal under reduced pressure. The oil was then triturated with hexanes, stored at $-30{ }^{\circ} \mathrm{C}$ for $1.5 \mathrm{~h}$, and dried under high vacuum at room 
temperature to yield the product as an off-white solid $(5.32 \mathrm{~g}, 77 \%) .{ }^{1} \mathrm{H} \mathrm{NMR}\left(500 \mathrm{MHz}, \mathrm{CDCl}_{3}\right)$ $\delta 8.58(\mathrm{~d}, J=4.6 \mathrm{~Hz}, 2 \mathrm{H}), 7.60(\mathrm{t}, J=7.8 \mathrm{~Hz}, 2 \mathrm{H}), 7.42(\mathrm{t}, J=7.8 \mathrm{~Hz}, 1 \mathrm{H}), 7.31(\mathrm{~d}, J=7.9 \mathrm{~Hz}$, $1 \mathrm{H}), 7.14(\mathrm{t}, J=6.2 \mathrm{~Hz}, 2 \mathrm{H}), 7.10-7.03(\mathrm{~m}, 3 \mathrm{H}), 2.30(\mathrm{~s}, 3 \mathrm{H}) \cdot{ }^{13} \mathrm{C} \mathrm{NMR}\left(126 \mathrm{MHz}, \mathrm{CDCl}_{3}\right) \delta$ $167.1,165.5,149.0,141.0,138.2,136.3,125.9,123.5,123.1,121.6,60.2,27.3$. ESI-MS $m / z$ for $[\mathrm{M}+\mathrm{H}]^{+}$requires 340.0444, found 340.0449. Anal. Calcd. for $\mathrm{C}_{17} \mathrm{H}_{14} \mathrm{BrN}_{3}: \mathrm{C}, 60.02 ; \mathrm{H}, 4.15 ; \mathrm{N}$, 12.35. Found: C, 60.15; H, 4.20; N, 12.13.

bpyClPY2Me. A $100 \mathrm{~mL}$ Schlenk flask equipped with a stir bar was charged with 2,2'-(1-(6bromopyridin-2-yl)ethane-1,1-diyl)dipyridine $\quad(2.11 \quad \mathrm{~g}, \quad 6.21 \quad \mathrm{mmol})$, 2-chloro-6(tributylstannyl)pyridine (3.00 g, $7.45 \mathrm{mmol}), \mathrm{Pd}\left(\mathrm{PPh}_{3}\right)_{4}(359 \mathrm{mg}, 310 \mu \mathrm{mol})$ and $m$-xylene (60 $\mathrm{mL})$. The reaction mixture was refluxed for $30 \mathrm{~h}$, then allowed to cool to room temperature before quenching with $200 \mathrm{~mL}$ of $10 \%(\mathrm{w} / \mathrm{w})$ aqueous KF. Subsequent workup was performed in air. The aqueous phase was extracted with $3 \times 150 \mathrm{~mL}$ of EtOAc. The combined organic phases were dried over $\mathrm{MgSO}_{4}$, filtered, and concentrated to a yellow oil by rotary evaporation. Purification by flash chromatography (silica, 1:1 hexanes:EtOAc, $\mathrm{R}_{\mathrm{f}}=0.23$ ) followed by rotary evaporation and drying under high vacuum at $40{ }^{\circ} \mathrm{C}$ for $8 \mathrm{~h}$ afforded the product as an off-white, sticky solid (1.12 g, 55\%). ${ }^{1} \mathrm{H}$ NMR $\left(500 \mathrm{MHz}, \mathrm{CDCl}_{3}\right) \delta 8.61(\mathrm{~d}, J=4.8 \mathrm{~Hz}, 2 \mathrm{H}), 8.26(\mathrm{~d}, J=7.7 \mathrm{~Hz}, 1 \mathrm{H}), 8.10(\mathrm{~d}$, $J=7.7 \mathrm{~Hz}, 1 \mathrm{H}), 7.72(\mathrm{t}, J=7.8 \mathrm{~Hz}, 1 \mathrm{H}), 7.61(\mathrm{dt}, J=31.4,7.6 \mathrm{~Hz}, 3 \mathrm{H}), 7.28(\mathrm{~s}, 1 \mathrm{H}), 7.21-7.06$ $(\mathrm{m}, 6 \mathrm{H}), 2.41(\mathrm{~s}, 3 \mathrm{H}) .{ }^{13} \mathrm{C} \mathrm{NMR}\left(126 \mathrm{MHz}, \mathrm{CDCl}_{3}\right) \delta 166.1,165.1,157.4,153.2,150.8,148.9$, $139.4,137.2$, 136.1, 124.4, 124.0, 123.7, 121.4, 119.7, 118.9, 60.5, 27.4. ESI-MS $m / z$ for $[\mathrm{M}+\mathrm{H}]^{+}$ requires 373.1215, found 373.1216. Anal. Calcd. for $\mathrm{C}_{22} \mathrm{H}_{17} \mathrm{ClN}_{4}: \mathrm{C}, 70.87 ; \mathrm{H}, 4.60 ; \mathrm{N}, 15.03$. Found: C, 71.13; H, 4.87; N, 14.64.

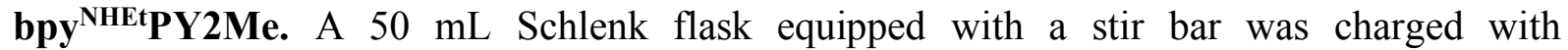
bpy ${ }^{\mathrm{Cl} P Y} 2 \mathrm{Me}(899 \mathrm{mg}, 2.41 \mathrm{mmol}), \mathrm{NaO}^{\mathrm{t}} \mathrm{Bu}(348 \mathrm{mg}, 3.63 \mathrm{mmol}),\left[\mathrm{Pd}\left(\mathrm{C}_{3} \mathrm{H}_{5}\right) \mathrm{Cl}\right]_{2}(4.4 \mathrm{mg}, 12$ $\mu \mathrm{mol})$, di(1-adamantyl)-2-dimethylaminophenylphosphine (10. $\mathrm{mg}, 24 \mu \mathrm{mol})$, and toluene (10 $\mathrm{mL}$ ). Ethylamine was condensed into a separate Schlenk tube cooled with liquid $\mathrm{N}_{2}$, then $\sim 4 \mathrm{~mL}$ of diethylamine $(\sim 70 \mathrm{mmol})$ was transferred to the reaction mixture via cannula. The reaction was heated to $100{ }^{\circ} \mathrm{C}$ for $12 \mathrm{~h}$, then allowed to cool to room temperature before quenching with 100 $\mathrm{mL}$ of aqueous $1 \mathrm{M} \mathrm{HCl}$. Subsequent workup was conducted in air. The aqueous phase was first extracted with $3 \times 100 \mathrm{~mL}$ of $\mathrm{CH}_{2} \mathrm{Cl}_{2}$ to remove unwanted byproducts and excess reagents. The aqueous phase was basified with $\mathrm{KOH}$ until the $\mathrm{pH}$ was $\sim 10$ and then extracted with $3 \times 100 \mathrm{~mL}$ of $\mathrm{Et}_{2} \mathrm{O}$. The combined organics were dried over $\mathrm{MgSO}_{4}$, filtered, and concentrated to $\sim 50 \mathrm{~mL}$ by rotary evaporation. Addition of hexanes $(200 \mathrm{~mL})$ and storage at $-30{ }^{\circ} \mathrm{C}$ for $8 \mathrm{~h}$ afforded colorless crystals, which were isolated and dried under high vacuum at $40^{\circ} \mathrm{C}$ for $8 \mathrm{~h}$ to give the product as a white, crystalline solid (651 mg, 71\%). ${ }^{1} \mathrm{H} \mathrm{NMR}\left(500 \mathrm{MHz}, \mathrm{CDCl}_{3}\right) \delta 8.59(\mathrm{~d}, J=4.9 \mathrm{~Hz}, 2 \mathrm{H})$, $8.19(\mathrm{~d}, J=7.9 \mathrm{~Hz}, 1 \mathrm{H}), 7.68(\mathrm{t}, J=7.8 \mathrm{~Hz}, 1 \mathrm{H}), 7.56(\mathrm{t}, J=7.8 \mathrm{~Hz}, 2 \mathrm{H}), 7.52-7.42(\mathrm{~m}, 2 \mathrm{H})$, $7.11(\mathrm{dt}, J=11.6,6.6 \mathrm{~Hz}, 5 \mathrm{H}), 6.37$ (d, $J=8.0 \mathrm{~Hz}, 1 \mathrm{H}), 4.49$ (br, 1H), $3.41-3.34(\mathrm{~m}, 2 \mathrm{H}), 2.41$ $(\mathrm{s}, 3 \mathrm{H}), 1.28(\mathrm{t}, J=7.1 \mathrm{~Hz}, 3 \mathrm{H}) .{ }^{13} \mathrm{C} \mathrm{NMR}\left(126 \mathrm{MHz}, \mathrm{CDCl}_{3}\right) \delta 166.5,164.5,148.8,138.3,136.8$, $135.9,123.9,123.2,121.2,118.3,110.5,106.8,100.1,60.4,37.1,27.3,15.1$. ESI-MS $m / z$ for $[\mathrm{M}+\mathrm{H}]^{+}$requires 382.2026, found 382.2032. Anal. Calcd. for $\mathrm{C}_{24} \mathrm{H}_{23} \mathrm{~N}_{5}: \mathrm{C}, 75.56 ; \mathrm{H}, 6.08 ; \mathrm{N}$, 18.36. Found: C, 75.51; H, 5.84; N, 18.02.

bpy ${ }^{\text {NEt2 }}$ PY2Me. A $25 \mathrm{~mL}$ Schlenk flask was charged with bpy ${ }^{\mathrm{Cl} P Y 2 M e}(225 \mathrm{mg}, 603 \mu \mathrm{mol})$, $\mathrm{NaO}{ }^{\mathrm{t}} \mathrm{Bu} \quad(87 \mathrm{mg}, \quad 910 \mu \mathrm{mol}), \quad\left[\mathrm{Pd}\left(\mathrm{C}_{3} \mathrm{H}_{5}\right) \mathrm{Cl}\right]_{2} \quad(1 \quad \mathrm{mg}, 3 \mu \mathrm{mol}), \quad$ di(1-adamantyl)-2dimethylaminophenylphosphine $(3 \mathrm{mg}, 6 \mu \mathrm{mol})$, and toluene $(3 \mathrm{~mL})$. Diethylamine $(\sim 1 \mathrm{~mL}, \sim 10$ mmol) was condensed into a Schlenk tube cooled with liquid $\mathrm{N}_{2}$, then transferred to the reaction mixture via cannula. The reaction was heated to $100{ }^{\circ} \mathrm{C}$ for 12 hours, then allowed to cool to room temperature before quenching with $50 \mathrm{~mL}$ of aqueous $1 \mathrm{M} \mathrm{HCl}$. Subsequent workup was 
conducted in air. The aqueous phase was first extracted with $3 \times 50 \mathrm{~mL}$ of $\mathrm{CH}_{2} \mathrm{Cl}_{2}$ to remove unwanted byproducts and excess reagents. The aqueous phase was basified with $\mathrm{KOH}$ until the $\mathrm{pH}$ was $\sim 14$ and then extracted with $3 \times 50 \mathrm{~mL}$ of EtOAc. The combined organics were dried over $\mathrm{MgSO}_{4}$, filtered, and concentrated by rotary evaporation, then further dried at $60{ }^{\circ} \mathrm{C}$ for $12 \mathrm{~h}$ to afford the product as an oily 0.2 EtOAc solvate as determined by ${ }^{1} \mathrm{H}$ NMR and elemental analysis (228 mg, 88\%). ${ }^{1} \mathrm{H}$ NMR (500 MHz, $\left.\mathrm{CDCl}_{3}\right) \delta 8.61(\mathrm{~d}, J=4.9 \mathrm{~Hz}, 2 \mathrm{H}), 8.23(\mathrm{~d}, J=7.9 \mathrm{~Hz}, 1 \mathrm{H})$, $7.69(\mathrm{t}, J=7.8 \mathrm{~Hz}, 1 \mathrm{H}), 7.58(\mathrm{t}, J=7.7 \mathrm{~Hz}, 2 \mathrm{H}), 7.43(\mathrm{~s}, 1 \mathrm{H}), 7.13(\mathrm{q}, J=7.4,6.8 \mathrm{~Hz}, 6 \mathrm{H}), 6.46$ (d, $J=7.6 \mathrm{~Hz}, 1 \mathrm{H}), 4.12$ (EtOAc), 3.58 (q, $J=7.1 \mathrm{~Hz}, 4 \mathrm{H}), 2.43$ (s, 3H), 2.05 (EtOAc), 1.25 (EtOAc), $1.21(\mathrm{t}, J=7.1 \mathrm{~Hz}, 6 \mathrm{H}) .{ }^{13} \mathrm{C} \mathrm{NMR}\left(126 \mathrm{MHz}, \mathrm{CDCl}_{3}\right) \delta 166.3,164.0,156.9,155.9,154.3$, $148.6,137.9,136.9,136.2,124.1,122.8,121.3,118.3,108.4,105.8,60.3,42.8,27.3$, 13.1. ESIMS $m / z$ for $[\mathrm{M}+\mathrm{H}]^{+}$requires 410.2339 , found 410.2342 . Anal. Calcd. for $\mathrm{C}_{26} \mathrm{H}_{27} \mathrm{~N}_{5} \cdot 0.2 \mathrm{C}_{4} \mathrm{H}_{8} \mathrm{O}$ : C, 75.36; H, 6.75; N, 16.40. Found: C, 75.78; H, 6.74; N, 15.97. 

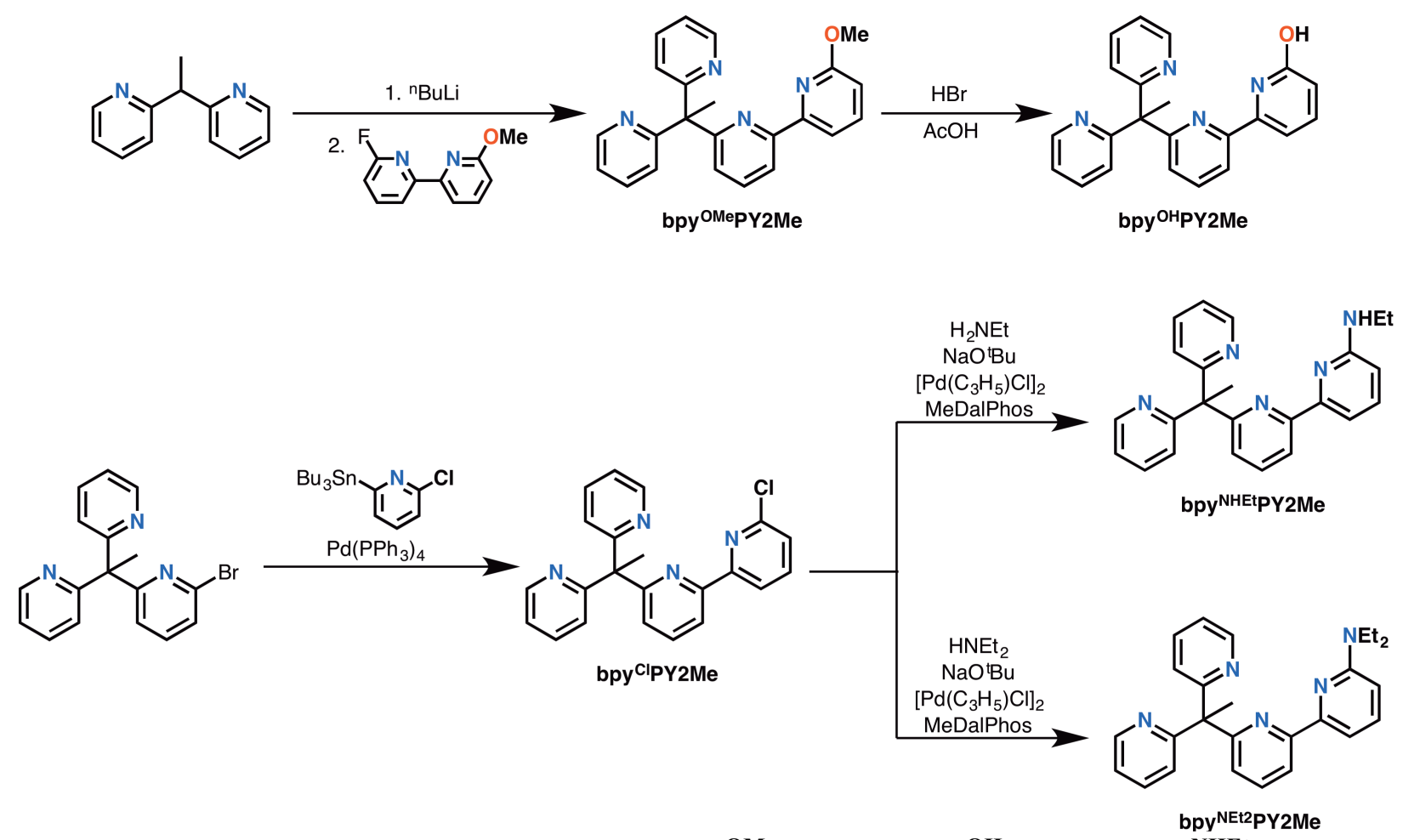

Scheme S1. Synthetic scheme for the ligands bpy ${ }^{\mathrm{OMe}}$ PY2Me, bpy ${ }^{\mathrm{OH}} \mathrm{PY} 2 \mathrm{Me}$, bpy ${ }^{\text {NHEtPY2Me, }}$ and bpy ${ }^{\text {NEt2 }}$ PY2Me. 


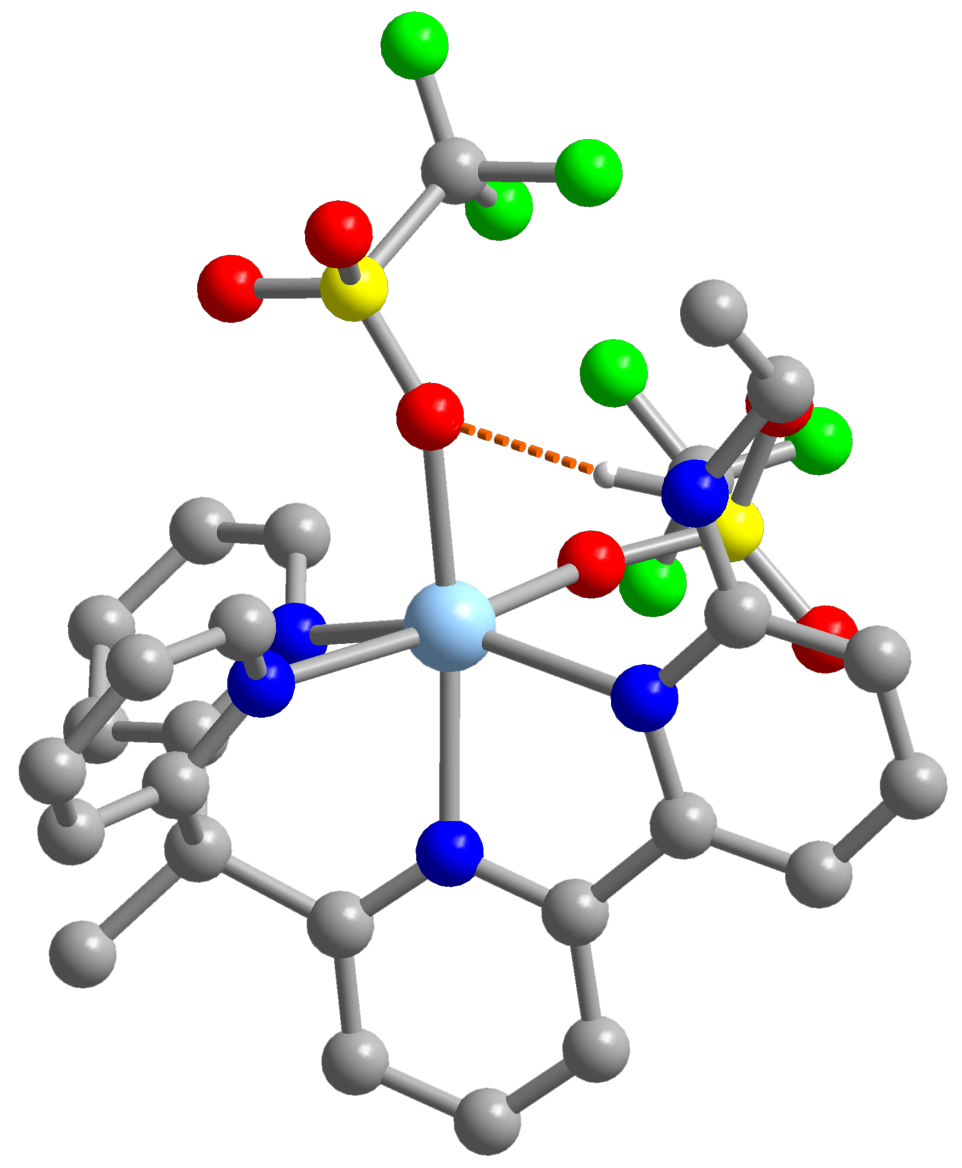

Figure S1. Single crystal X-ray structure of complex 6. Light blue, blue, gray, red, yellow, green, and white spheres represent $\mathrm{Mn}, \mathrm{N}, \mathrm{C}, \mathrm{O} \mathrm{S}, \mathrm{F}$, and $\mathrm{H}$ atoms, respectively. Hydrocarbon $\mathrm{H}$ atoms and unbound solvent molecules are not shown. 
Table S1. Crystallographic data for complexes $2-6^{a}$

\begin{tabular}{|c|c|c|c|}
\hline & 2 & 3 & 4 \\
\hline formula & $\mathrm{C}_{28} \mathrm{H}_{24} \mathrm{~F}_{6} \mathrm{FeN}_{6} \mathrm{O}_{7} \mathrm{~S}_{2}$ & $\mathrm{C}_{33} \mathrm{H}_{32} \mathrm{~F}_{6} \mathrm{FeN}_{8} \mathrm{O}_{7} \mathrm{~S}_{2}$ & $\mathrm{C}_{26} \mathrm{H}_{23} \mathrm{~F}_{6} \mathrm{FeN}_{5} \mathrm{O}_{6} \mathrm{~S}_{2}$ \\
\hline crystal system & triclinic & triclinic & monoclinic \\
\hline fw, $g \mathrm{~mol}^{-1}$ & 790.50 & 886.63 & 735.46 \\
\hline$T, \mathrm{~K}$ & $100(2)$ & $100(2)$ & $100(2)$ \\
\hline space group & $P \overline{1}$ & $P \overline{1}$ & $P 2_{1} / c$ \\
\hline habit & block & block & block \\
\hline color & brown & red & brown \\
\hline$Z$ & 2 & 2 & 4 \\
\hline$a, \AA$ & $10.5333(8)$ & $12.5851(7)$ & $15.4307(6)$ \\
\hline$b, \AA$ & $13.0119(9)$ & $12.6151(7)$ & $11.1704(4)$ \\
\hline$c, \AA$ & $13.0285(10)$ & $14.8628(8)$ & $18.2742(7)$ \\
\hline$\alpha,{ }^{\circ}$ & $104.106(4)$ & $113.007(2)$ & 90 \\
\hline$\beta,{ }^{\circ}$ & $113.539(4)$ & $93.593(3)$ & $110.4350(10)$ \\
\hline$\gamma,{ }^{\circ}$ & $94.581(4)$ & $116.284(2)$ & 90 \\
\hline$V, \AA^{3}$ & $1555.9(2)$ & $1866.26(18)$ & 2951.64(19) \\
\hline$\rho_{\text {calc }}, \mathrm{g} \mathrm{cm}^{-3}$ & 1.687 & 1.578 & 1.655 \\
\hline$\mu_{\text {calc }}, \mathrm{mm}^{-1}$ & 0.713 & 0.605 & 0.741 \\
\hline $2 \theta$ range $^{\circ}$ & 3.294 to 50.796 & 3.106 to 50.836 & 2.816 to 50.732 \\
\hline total reflections & 24996 & 46480 & 46906 \\
\hline data / restr / parameters & $5691 / 0 / 458$ & $6816 / 0 / 520$ & 5404 / 0 / 421 \\
\hline$F(000)$ & 804 & 908 & 1496 \\
\hline$T_{\min } / T_{\max }$ & 0.916 & 0.923 & 0.904 \\
\hline $\begin{array}{l}\text { crystal size, } \\
\mathrm{mm}^{3}\end{array}$ & $0.23 \times 0.21 \times 0.18$ & $0.34 \times 0.31 \times 0.23$ & $0.38 \times 0.3 \times 0.21$ \\
\hline $\begin{array}{l}\text { Largest diff. peak/hole } \\
\qquad / \text { e } \AA^{-3}\end{array}$ & $1.04 /-0.44$ & $0.61 /-0.47$ & $0.41 /-0.33$ \\
\hline $\begin{array}{c}R_{1}\left(w R_{2}\right),{ }^{b} \% \\
{[I>2 \sigma(I)]}\end{array}$ & $4.35(8.67)$ & $3.68(8.47)$ & $2.36(6.01)$ \\
\hline $\begin{array}{l}R_{1}\left(w R_{2}\right), \% \\
\text { (all data) }\end{array}$ & $6.81(9.68)$ & $4.57(8.89)$ & $2.57(6.16)$ \\
\hline
\end{tabular}

${ }^{a}$ Obtained with graphite-monochromated Mo $\mathrm{K} \alpha(\lambda=0.71073 \AA)$ radiation.

${ }^{b} R_{1}=\sum|| F_{\mathrm{o}}|-| F_{\mathrm{c}}|| / \sum\left|F_{\mathrm{o}}\right|, w R_{2}=\left\{\sum w\left(F_{\mathrm{o}}^{2}-F_{\mathrm{c}}^{2}\right)^{2} / \sum w\left(F_{\mathrm{o}}^{2}\right)^{2}\right\}^{\frac{1}{2}}$ 
Table S1 (continued). Crystallographic data for complexes $1-6 .{ }^{a}$

\begin{tabular}{|c|c|c|}
\hline & $\mathbf{5}^{c}$ & 6 \\
\hline formula & $\mathrm{C}_{30} \mathrm{H}_{30} \mathrm{~F}_{6} \mathrm{FeN}_{6} \mathrm{O}_{6} \mathrm{~S}_{2}$ & $\mathrm{C}_{26} \mathrm{H}_{23} \mathrm{~F}_{6} \mathrm{MnN}_{5} \mathrm{O}_{6} \mathrm{~S}_{2}$ \\
\hline crystal system & triclinic & monoclinic \\
\hline fw, $g \mathrm{~mol}^{-1}$ & 804.57 & 734.55 \\
\hline$T, \mathrm{~K}$ & $100(2)$ & $250(2)$ \\
\hline space group & $P \overline{1}$ & $P 2_{1} / c$ \\
\hline habit & block & block \\
\hline color & yellow-orange & yellow \\
\hline$Z$ & 2 & 4 \\
\hline$a, \AA$ & $12.2693(6)$ & $15.7289(16)$ \\
\hline$b, \AA$ & $13.0429(7)$ & $11.2251(11)$ \\
\hline$c, \AA$ & $13.4976(6)$ & $18.4618(19)$ \\
\hline$\alpha,^{\circ}$ & $107.264(2)$ & 90 \\
\hline$\beta,{ }^{\circ}$ & $113.727(2)$ & $109.666(2)$ \\
\hline$\gamma,{ }^{\circ}$ & $101.057(2)$ & 90 \\
\hline$V, \AA^{3}$ & $1764.63(15)$ & $3069.5(5)$ \\
\hline$\rho_{\text {calc }}, \mathrm{g} \mathrm{cm}^{-3}$ & 1.514 & 1.59 \\
\hline$\mu_{\text {calc }}, \mathrm{mm}^{-1}$ & 0.628 & 0.651 \\
\hline $2 \theta$ range, $^{\circ}$ & 3.5 to 50.746 & 2.75 to 50.762 \\
\hline total reflections & 29803 & 35531 \\
\hline data / restr / parameters & $6422 / 420 / 528$ & $5625 / 0 / 421$ \\
\hline$F(000)$ & 824 & 1492 \\
\hline$T_{\min } / T_{\max }$ & 0.935 & 0.872 \\
\hline $\begin{array}{l}\text { crystal size, } \\
\mathrm{mm}^{3}\end{array}$ & $0.08 \times 0.06 \times 0.06$ & $0.6 \times 0.3 \times 0.3$ \\
\hline $\begin{array}{l}\text { Largest diff. peak/hole } \\
\text { / e } \AA^{-3}\end{array}$ & $1.48 /-0.95$ & $1.17 /-0.59$ \\
\hline $\begin{array}{c}R_{1}\left(w R_{2}\right),{ }^{b} \% \\
{[I>2 \sigma(I)]}\end{array}$ & $5.79(14.41)$ & $5.57(15.43)$ \\
\hline $\begin{array}{l}R_{1}\left(w R_{2}\right), \% \\
\quad \text { (all data) }\end{array}$ & $6.47(14.92)$ & $6.54(16.46)$ \\
\hline
\end{tabular}

${ }^{a}$ Obtained with graphite-monochromated Mo $\mathrm{K} \alpha(\lambda=0.71073 \AA)$ radiation.

${ }^{b} R_{1}=\sum|| F_{\mathrm{o}}|-| F_{\mathrm{c}}|| / \sum\left|F_{\mathrm{o}}\right|, w R_{2}=\left\{\sum w\left(F_{\mathrm{o}}^{2}-F_{\mathrm{c}}^{2}\right)^{2} / \sum w\left(F_{\mathrm{o}}^{2}\right)^{2}\right\}^{\frac{1}{2}}$

${ }^{c}$ The empirical formula and formula weight of 5 does not include unidentified, disordered solvent. 


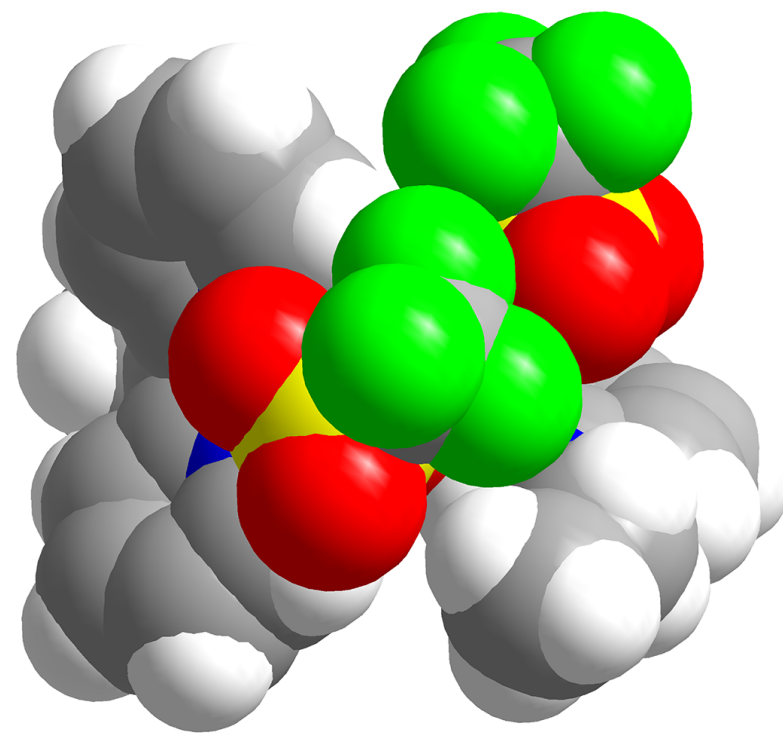

4

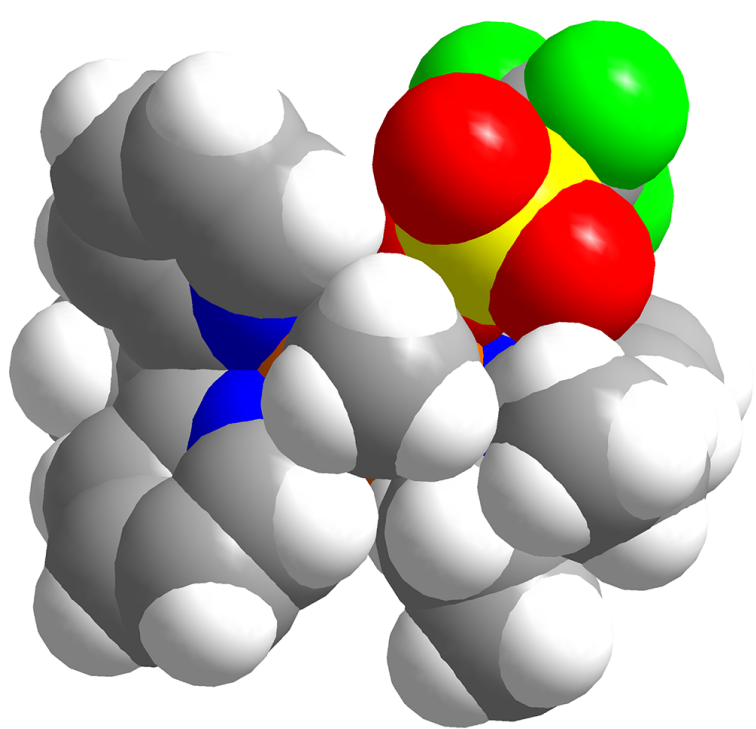

5

Figure S2. Space-filling views of complexes $\mathbf{4}$ and $\mathbf{5}$ along the $\mathrm{L}_{1}-\mathrm{Fe}$ vector, highlighting the steric interactions between the $\mathrm{CF}_{3} \mathrm{SO}_{3}{ }^{-}$ligand with the NHEt group in complex 4 and the $\mathrm{CH}_{3} \mathrm{CN}$ ligand with the $\mathrm{NEt}_{2}$ group in complex 5. Orange, blue, gray, red, yellow, green, and white spheres represent $\mathrm{Fe}, \mathrm{N}, \mathrm{C}, \mathrm{O} \mathrm{S}, \mathrm{F}$, and $\mathrm{H}$ atoms, respectively. 
Table S2. Highlighted crystallographic bond distances for complexes 1-6.

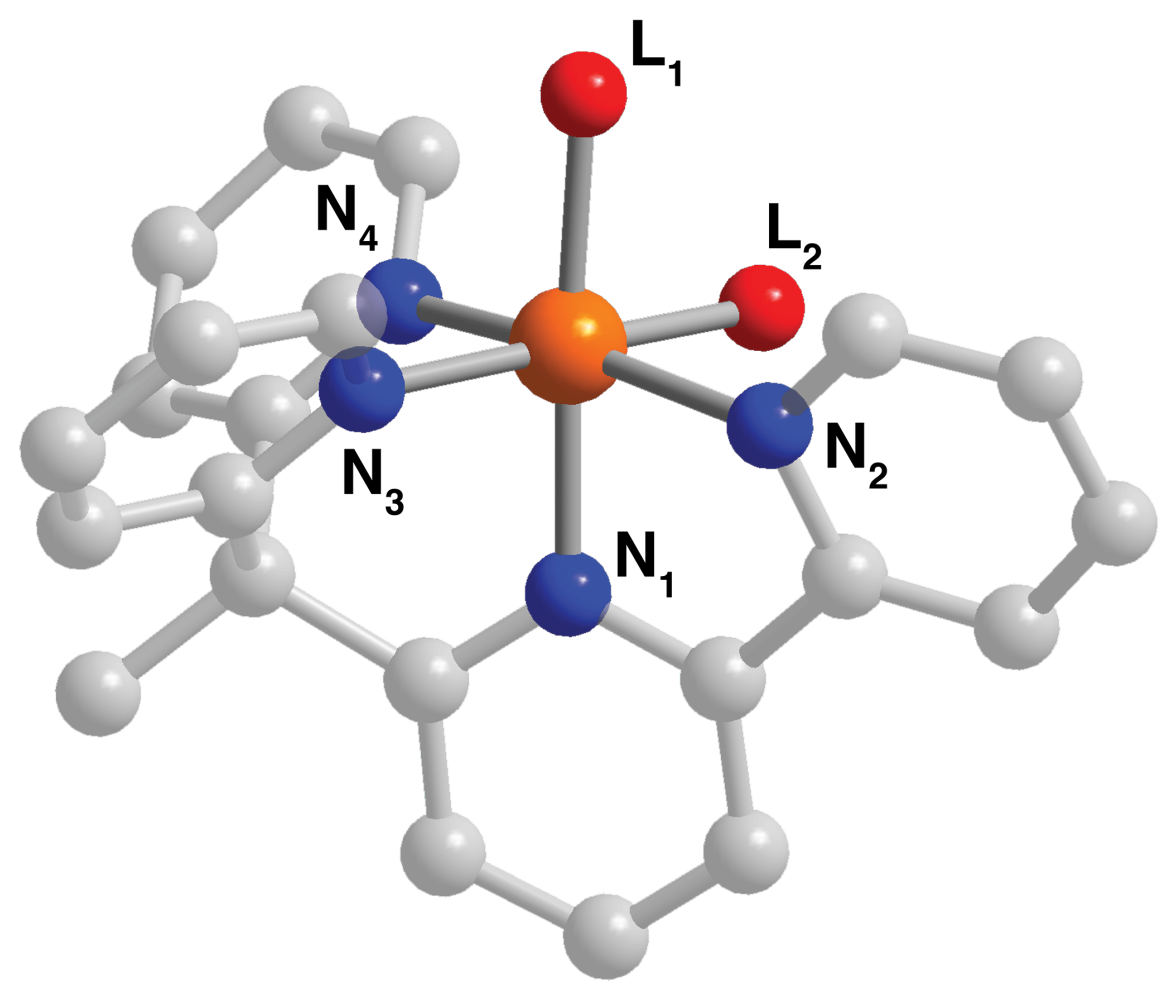

\begin{tabular}{ccccccc}
\hline Bond, $\mathbf{\AA}$ & \multicolumn{6}{c}{ Complex } \\
& $\mathbf{1}^{a}$ & $\mathbf{2}$ & $\mathbf{3}$ & $\mathbf{4}$ & $\mathbf{5}$ & $\mathbf{6}$ \\
\hline $\mathrm{M}-\mathrm{N}_{1}$ & $1.903(1)$ & $1.905(3)$ & $1.905(1)$ & $2.109(1)$ & $2.106(2)$ & $2.192(3)$ \\
$\mathrm{M}-\mathrm{N}_{2}$ & $1.992(1)$ & $2.053(2)$ & $2.043(3)$ & $2.204(1)$ & $2.249(4)$ & $2.253(3)$ \\
$\mathrm{M}-\mathrm{N}_{3}$ & $1.952(2)$ & $1.955(3)$ & $1.942(2)$ & $2.169(1)$ & $2.184(4)$ & $2.261(3)$ \\
$\mathrm{M}-\mathrm{N}_{4}$ & $1.970(2)$ & $1.974(3)$ & $1.970(3)$ & $2.138(1)$ & $2.175(3)$ & $2.203(3)$ \\
$\mathrm{M}-\mathrm{L}_{1}{ }^{b}$ & $1.953(2)$ & $1.949(3)$ & $1.942(2)$ & $2.087(1)$ & $2.108(3)$ & $2.135(3)$ \\
$\mathrm{M}-\mathrm{L}_{2}{ }^{c}$ & $1.945(2)$ & $1.958(3)$ & $1.951(2)$ & $2.167(1)$ & $2.182(3)$ & $2.172(3)$ \\
\hline
\end{tabular}

${ }^{a}$ Crystallographic distances from ref 2 .

${ }^{b} \mathrm{~L}_{1}=\mathrm{CH}_{3} \mathrm{CN}$ for $\mathbf{1}, \mathbf{2}, \mathbf{3}$, and $\mathbf{5} ; \mathrm{L}_{2}=\mathrm{CF}_{3} \mathrm{SO}_{3}{ }^{-}$for 4 and $\mathbf{6}$.

${ }^{c} \mathrm{~L}_{2}=\mathrm{CH}_{3} \mathrm{CN}$ for $\mathbf{1 - 3} \cdot \mathrm{L}_{1}=\mathrm{CF}_{3} \mathrm{SO}_{3}{ }^{-}$for 4-6. 


\section{Cyclic Voltammograms of Complexes in Acetonitrile With Variable Scan Rate}
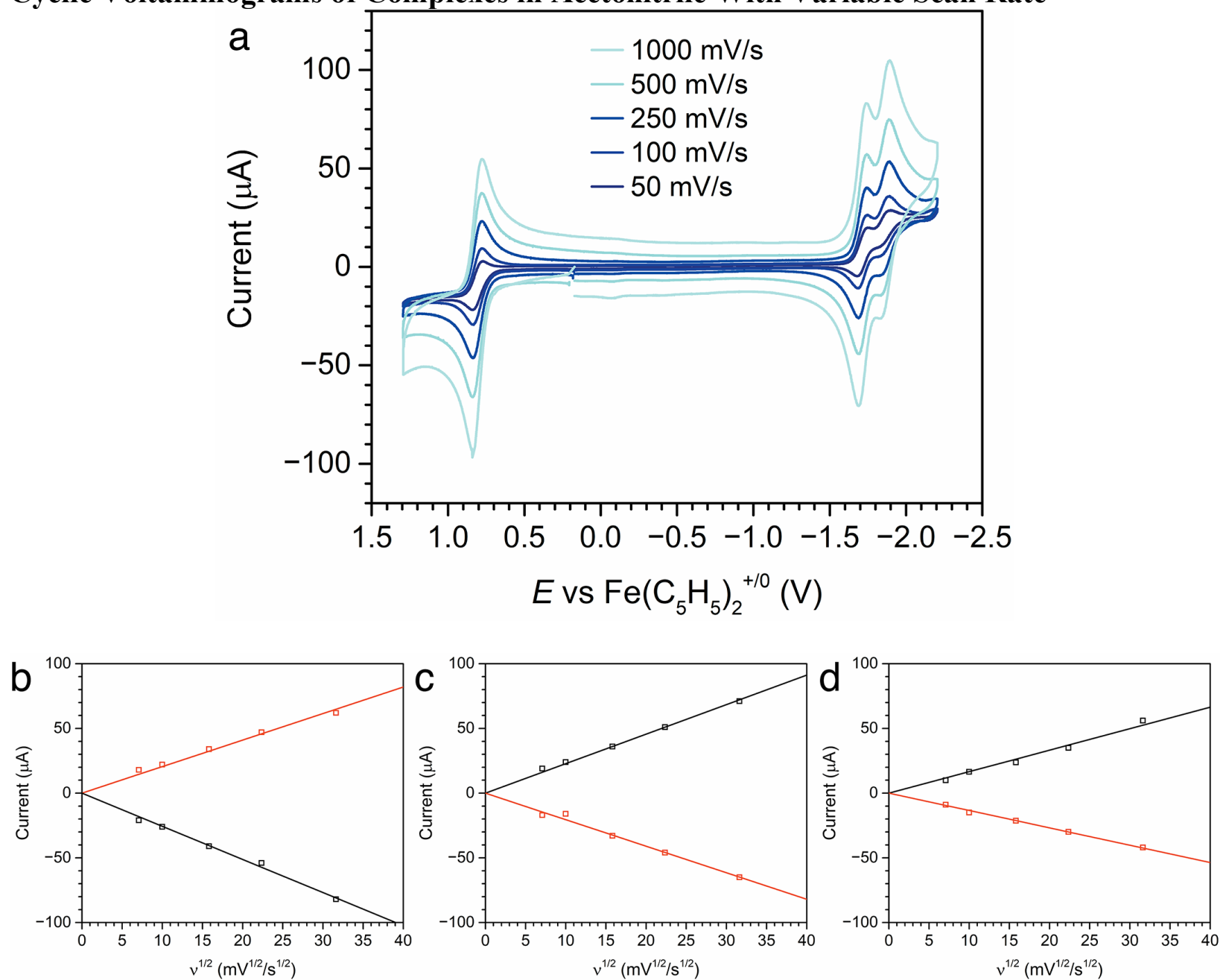

Figure S3. (a) CVs of complex 1 in argon-saturated acetonitrile solution with $0.1 \mathrm{M} \mathrm{NBu}_{4} \mathrm{PF}_{6}$ supporting electrolyte, with scan rates of $50 \mathrm{mV} / \mathrm{s}$ to $1000 \mathrm{mV} / \mathrm{s}$, sweeping first to positive potentials. Plots of peak current versus square root of scan rate for forward (black squares) and reverse (red squares) sweeps of the redox couple centered at (b) $+0.81 \mathrm{~V}$, (c) $-1.71 \mathrm{~V}$, and (d) $-1.86 \mathrm{~V}$. Black and red lines are the corresponding linear fits. 

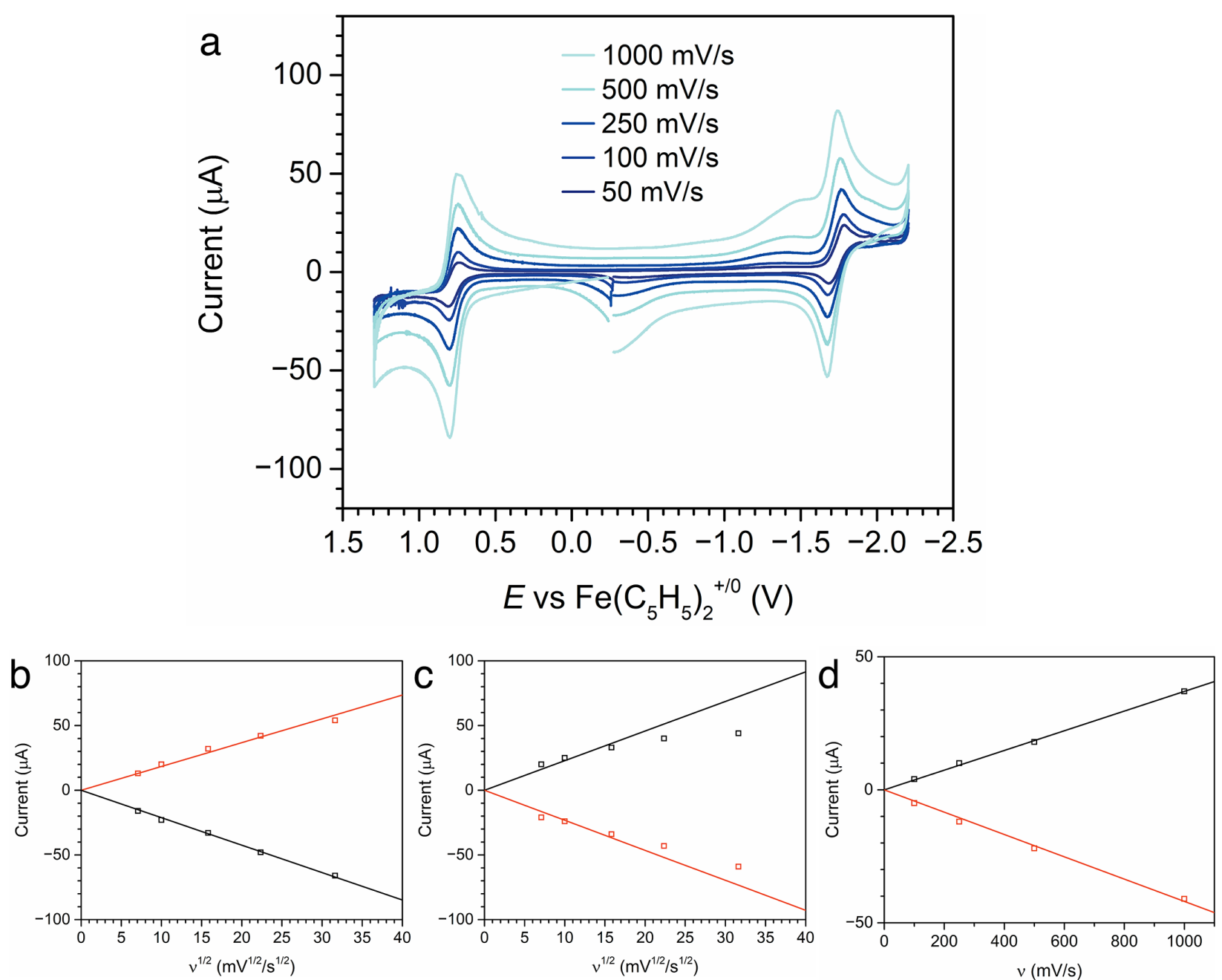

Figure S4. (a) CVs of complex 3 in argon-saturated acetonitrile solution with $0.1 \mathrm{M} \mathrm{NBu}_{4} \mathrm{PF}_{6}$ supporting electrolyte, with scan rates of $50 \mathrm{mV} / \mathrm{s}$ to $1000 \mathrm{mV} / \mathrm{s}$, sweeping first to positive potentials. Plots of peak current versus square root of scan rate for forward (black squares) and reverse (red squares) sweeps of the redox couple centered at (b) $+0.78 \mathrm{~V}$ and (c) $-1.72 \mathrm{~V}$. We attribute the deviation of from ideal behavior predicted by the Cottrell equation due to interference from a broad, preceding feature apparent at $v \geq 250 \mathrm{mV} / \mathrm{s}$. (d) Plot of peak current versus scan rate for the forward (black squares) and reverse (red squares) sweeps of the broad features occurring at $E_{\mathrm{pc}} \approx-1.2 \mathrm{~V}$ and $E_{\mathrm{pa}} \approx-0.2 \mathrm{~V}$. Black and red lines are the corresponding linear fits. 

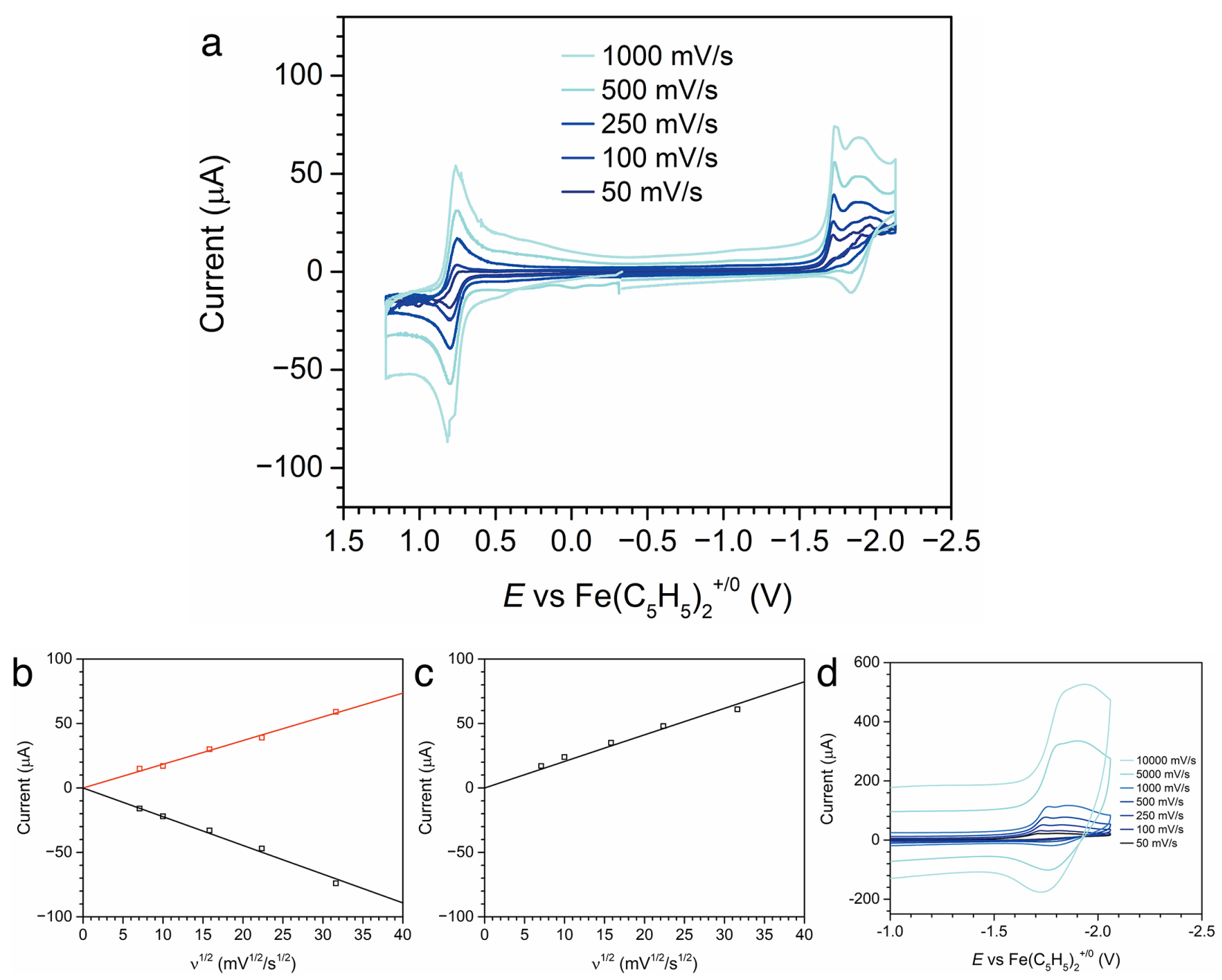

Figure S5. (a) CVs of complex 2 in argon-saturated acetonitrile solution with $0.1 \mathrm{M} \mathrm{NBu}_{4} \mathrm{PF}_{6}$ supporting electrolyte, with scan rates of $50 \mathrm{mV} / \mathrm{s}$ to $1000 \mathrm{mV} / \mathrm{s}$, sweeping first to positive potentials. (b) Plot of peak current versus square root of scan rate for forward (black squares) and reverse (red squares) sweeps of the redox couple centered at $+0.78 \mathrm{~V}$. (c) Plot of peak current versus square root of scan rate for the forward sweep of the redox couple with $E_{\mathrm{p}}=-1.72 \mathrm{~V}$. (d) $\mathrm{CVs}$ at $c a$. $-1.7 \mathrm{~V}$ at scan rates up to $10 \mathrm{~V} / \mathrm{s}$. The two features forward, reductive features appear to merge into one redox couple centered at $-1.71 \mathrm{~V}$. 

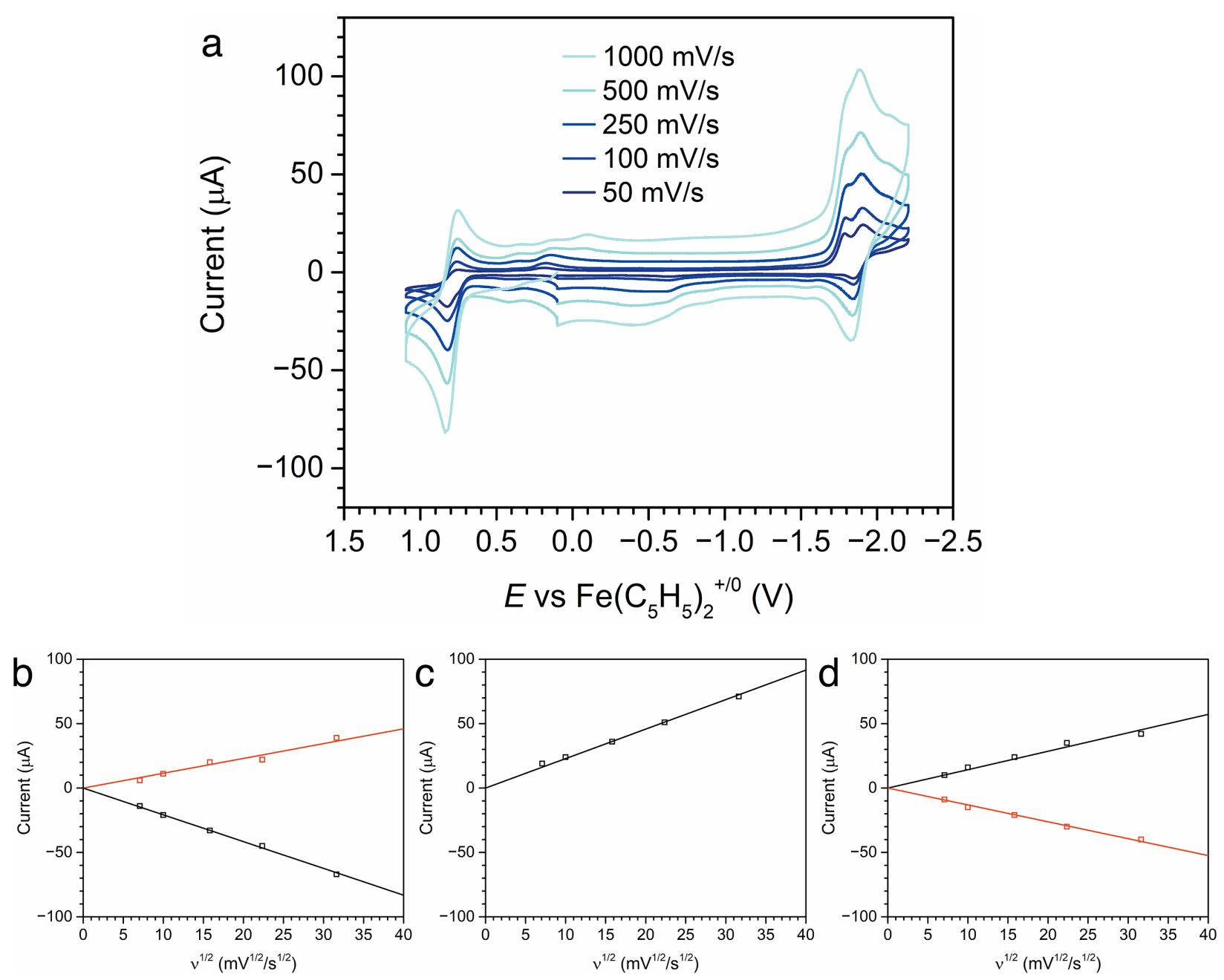

Figure S6. (a) CVs of complex 4 in argon-saturated acetonitrile solution with $0.1 \mathrm{M} \mathrm{NBu}_{4} \mathrm{PF}_{6}$ supporting electrolyte, with scan rates of $50 \mathrm{mV} / \mathrm{s}$ to $1000 \mathrm{mV} / \mathrm{s}$, sweeping first to positive potentials. Plots of peak current versus square root of scan rate for forward (black squares) and reverse (red squares) sweeps of the redox couples with (b) $E_{1 / 2}=+0.80 \mathrm{~V}$, (c) $E_{\mathrm{pc}}=-1.79 \mathrm{~V}$, and (d) $E_{1 / 2}=-1.87 \mathrm{~V}$. Black and red lines are the corresponding linear fits. 

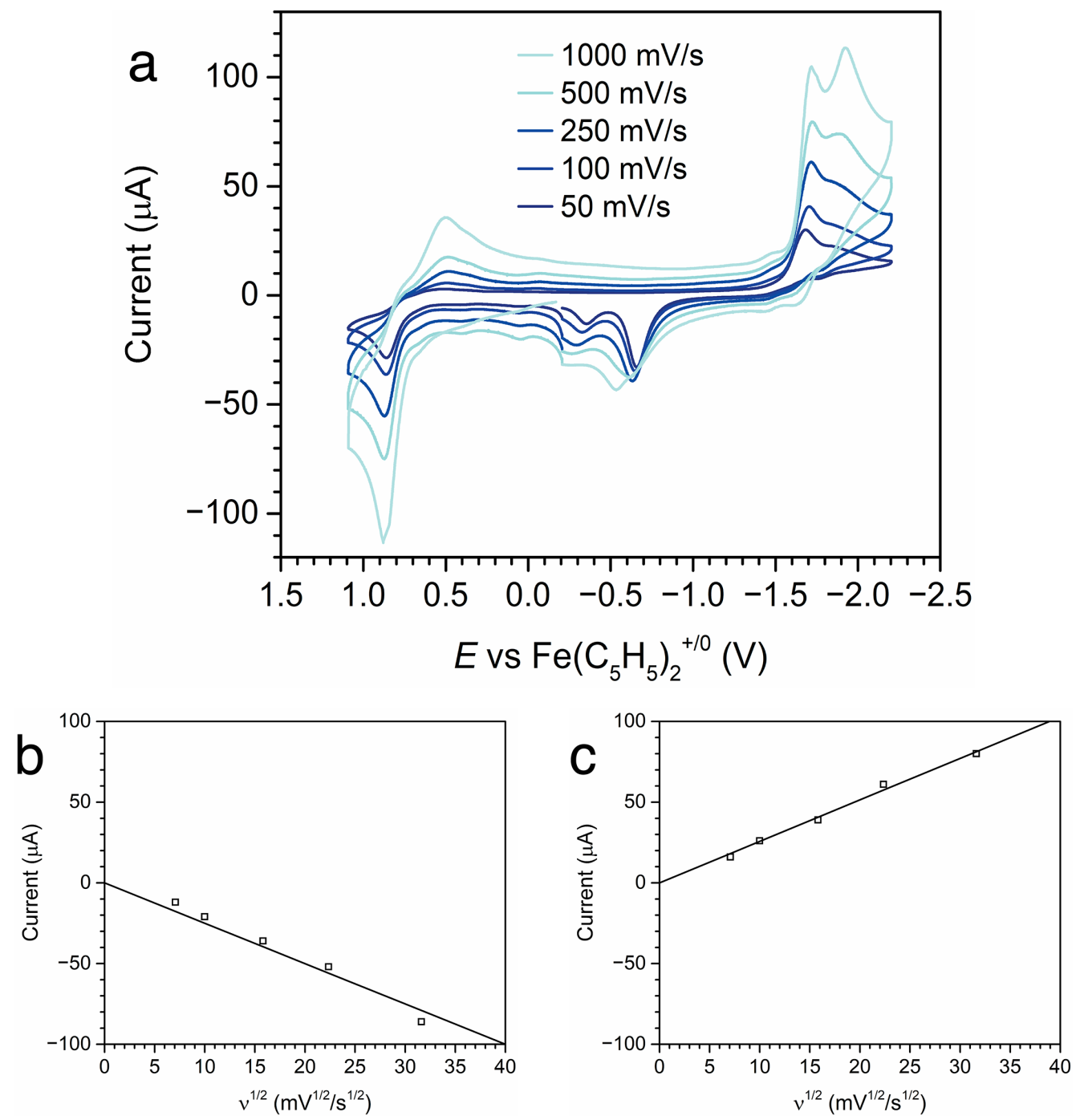

Figure S7. (a) CVs of complex 5 in argon-saturated acetonitrile solution with $0.1 \mathrm{M} \mathrm{NBu}_{4} \mathrm{PF}_{6}$ supporting electrolyte, with scan rates of $50 \mathrm{mV} / \mathrm{s}$ to $1000 \mathrm{mV} / \mathrm{s}$, sweeping first to positive potentials. Plots of peak current versus square root of scan rate for forward sweeps of the redox couples with (b) $E_{\mathrm{pa}}=+0.87 \mathrm{~V}$, and (c) $E_{\mathrm{pc}}=-1.71 \mathrm{~V}$. Black lines are the corresponding linear fits. 

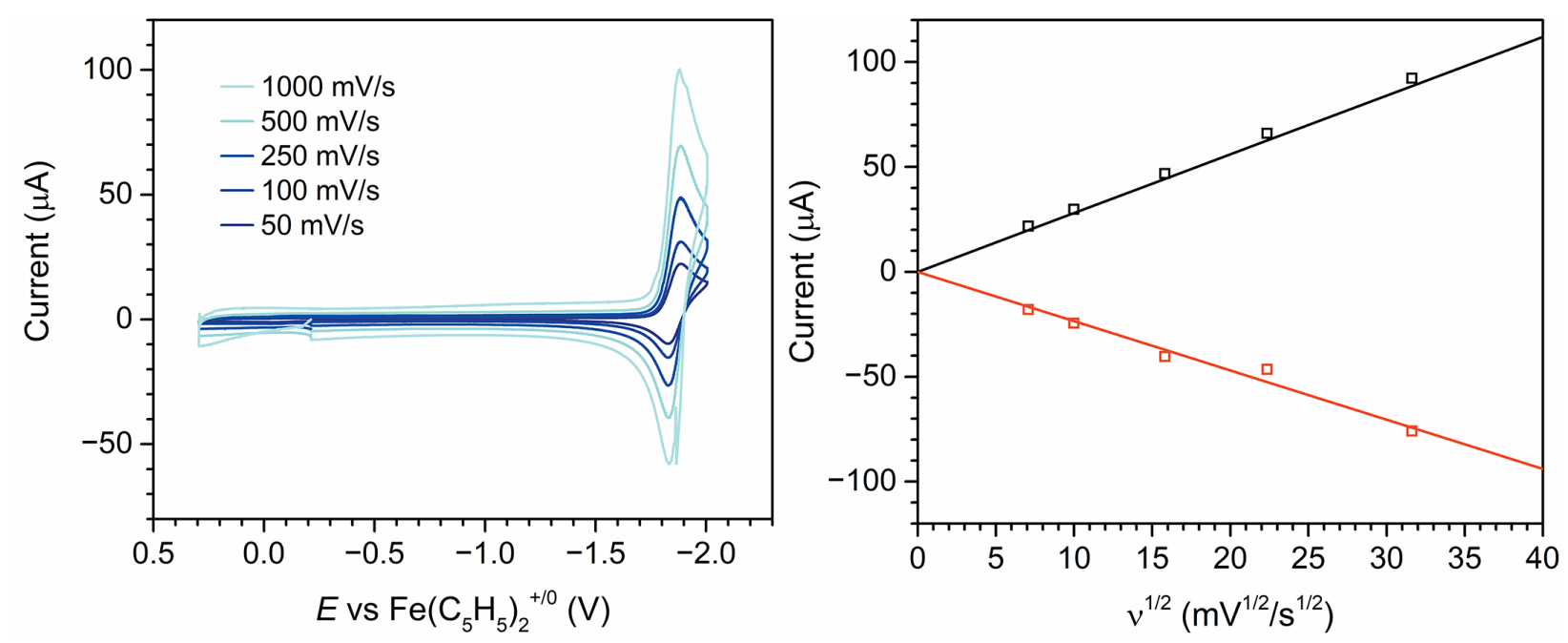

Figure S8. Left: $\mathrm{CV}$ s of complex 6 in argon-saturated acetonitrile solution with $0.1 \mathrm{M} \mathrm{NBu}_{4} \mathrm{PF}_{6}$ supporting electrolyte, with scan rates of $50 \mathrm{mV} / \mathrm{s}$ to $1000 \mathrm{mV} / \mathrm{s}$, sweeping first to positive potentials. Right: Plot of peak current versus square root of scan rate for forward (black squares) and reverse (red squares) sweeps of the redox couple with $E_{1 / 2}=-1.85 \mathrm{~V}$. Black and red lines are the corresponding linear fits. 


\section{Electronic Absorption Spectra of Fe Complexes in Acetonitrile and Water Mixtures}

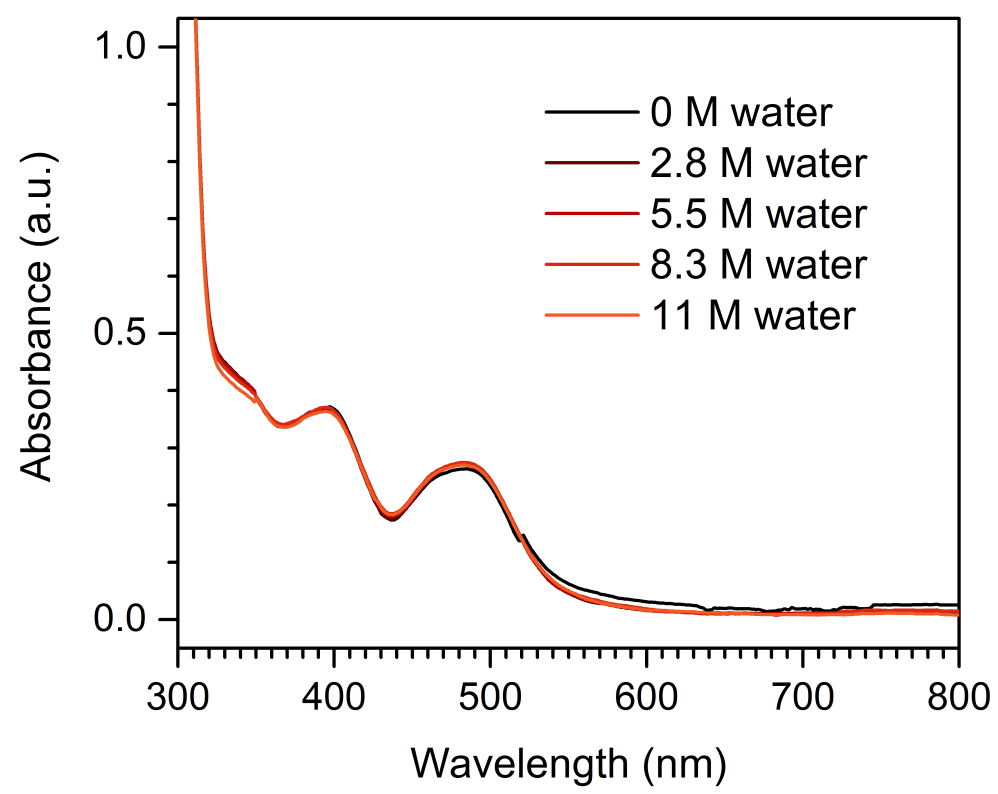

Figure S9. UV-vis spectra of complex 1 in acetonitrile and increasing concentrations of water. The addition of water causes minimal perturbation in the electronic absorption spectrum, consistent with a substitutionally inert low-spin $d^{6} \mathrm{Fe}(\mathrm{II})$ complex.

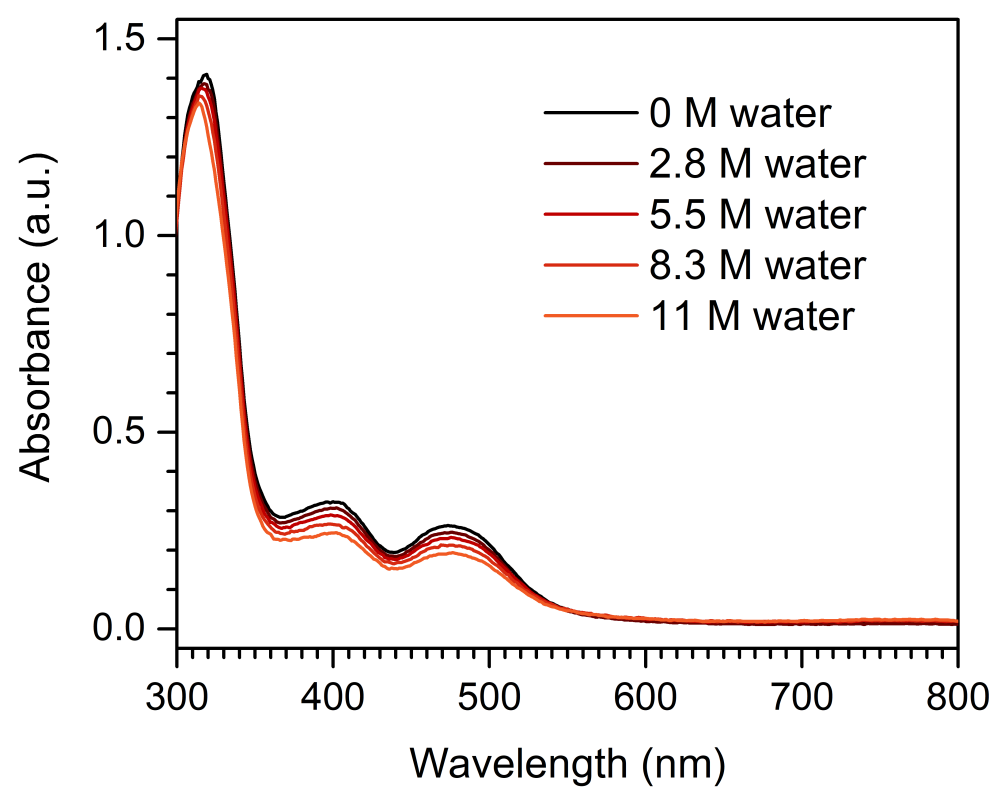

Figure S10. UV-vis spectra of complex 3 in acetonitrile and increasing concentrations of water. The addition of water causes minimal perturbation in the electronic absorption spectrum, consistent with a substitutionally inert low-spin $d^{6} \mathrm{Fe}(\mathrm{II})$ complex. 


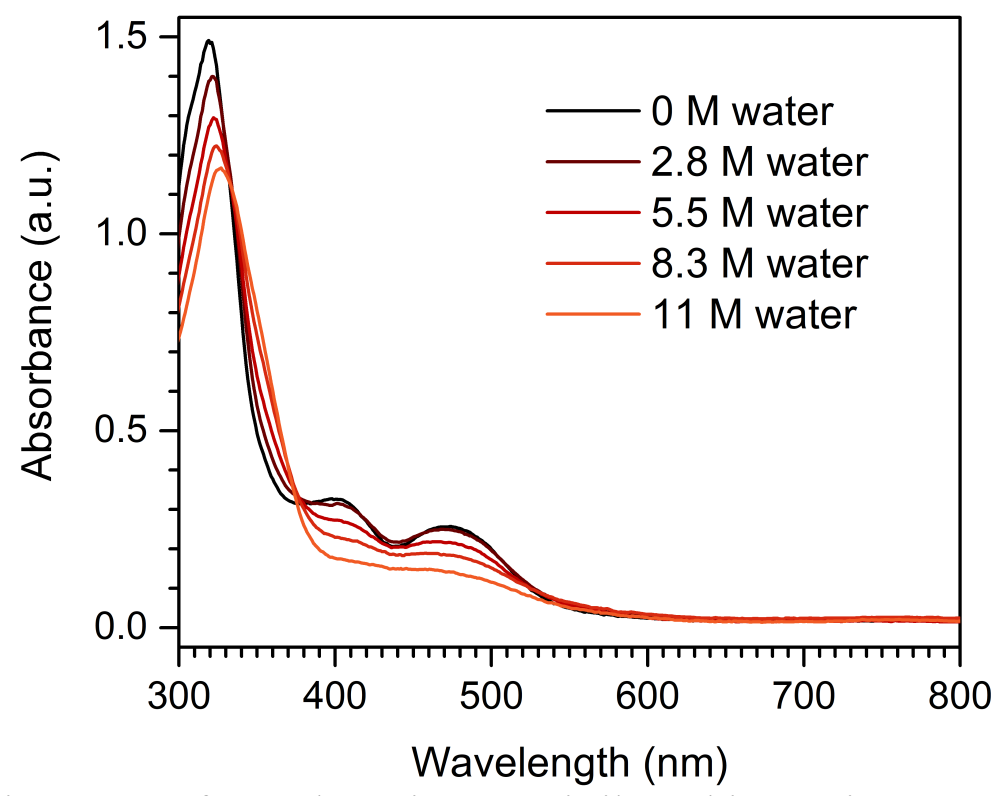

Figure S11. UV-vis spectra of complex 2 in acetonitrile and increasing concentrations of water. Although complex 2 has low-spin Fe(II), addition of water continuously perturbs the electronic absorption spectrum, possibly due to hydrogen bonding or acid-base chemistry through the second coordination sphere $\mathrm{OH}$ group.

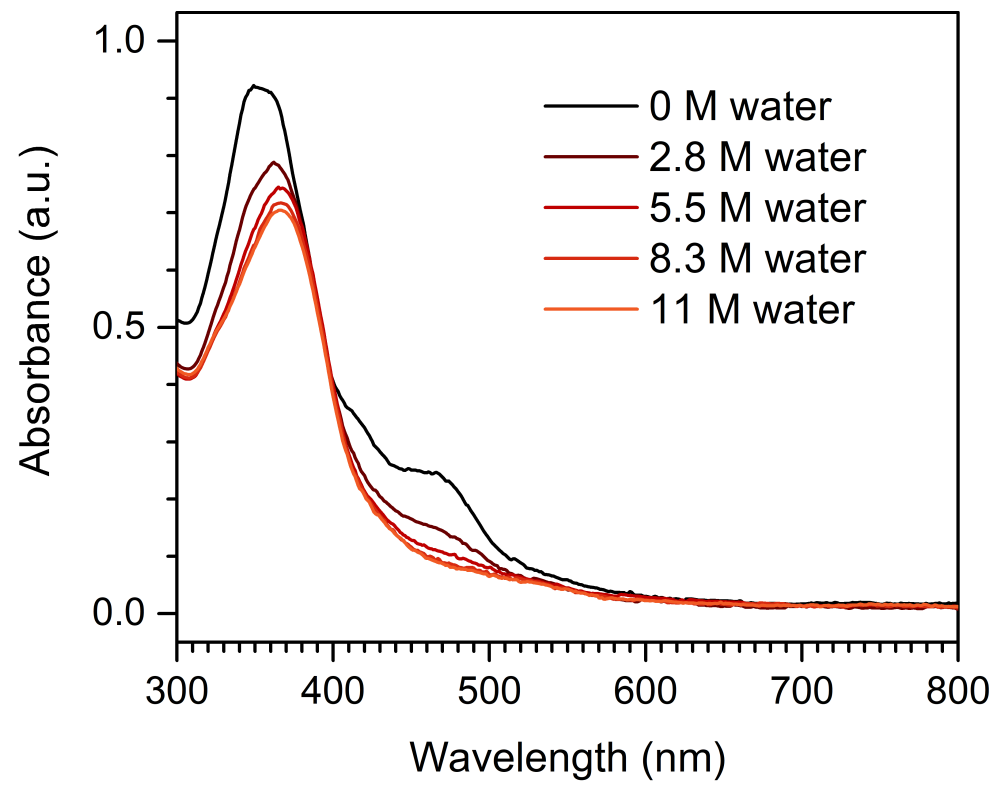

Figure S12. UV-vis spectra of complex 4 in acetonitrile and increasing concentrations of water. The addition of water perturbs the electronic absorption spectrum, suggesting aquo ligands are displacing one or more acetonitrile ligands at the Fe(II) ion. 


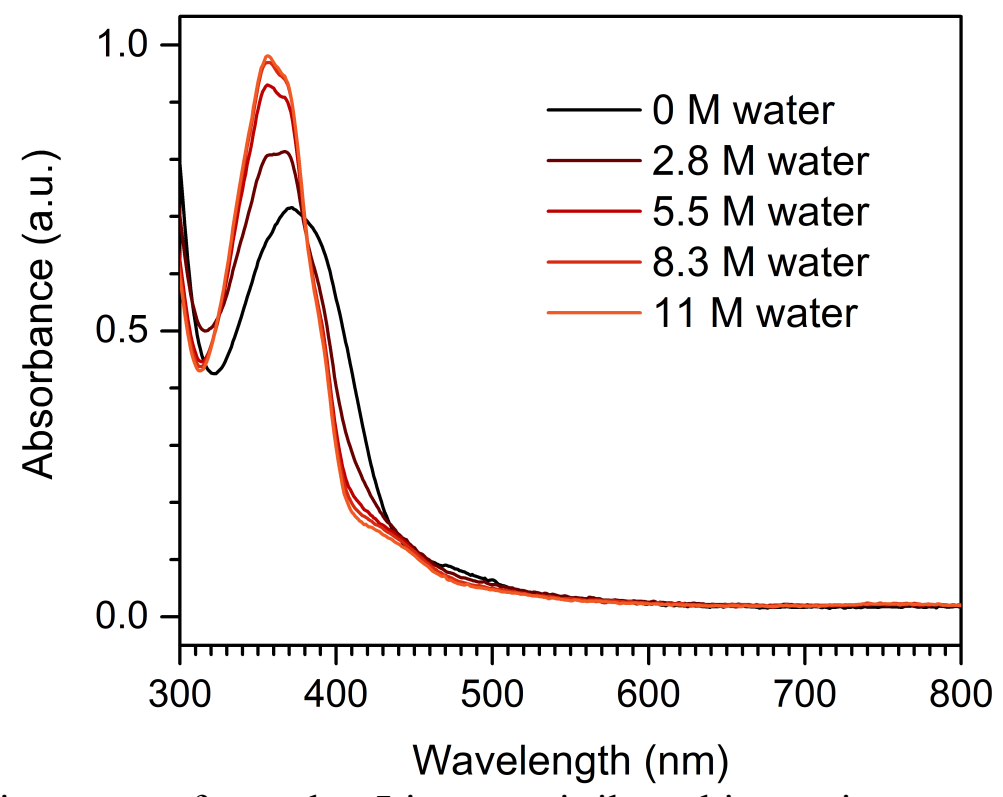

Figure S13. UV-vis spectra of complex 5 in acetonitrile and increasing concentrations of water. The addition of water addition of water continuously perturbs the electronic absorption spectrum, consistent with aquo ligands displacing acetonitrile from coordinating the $\mathrm{Fe}(\mathrm{II})$ center. 


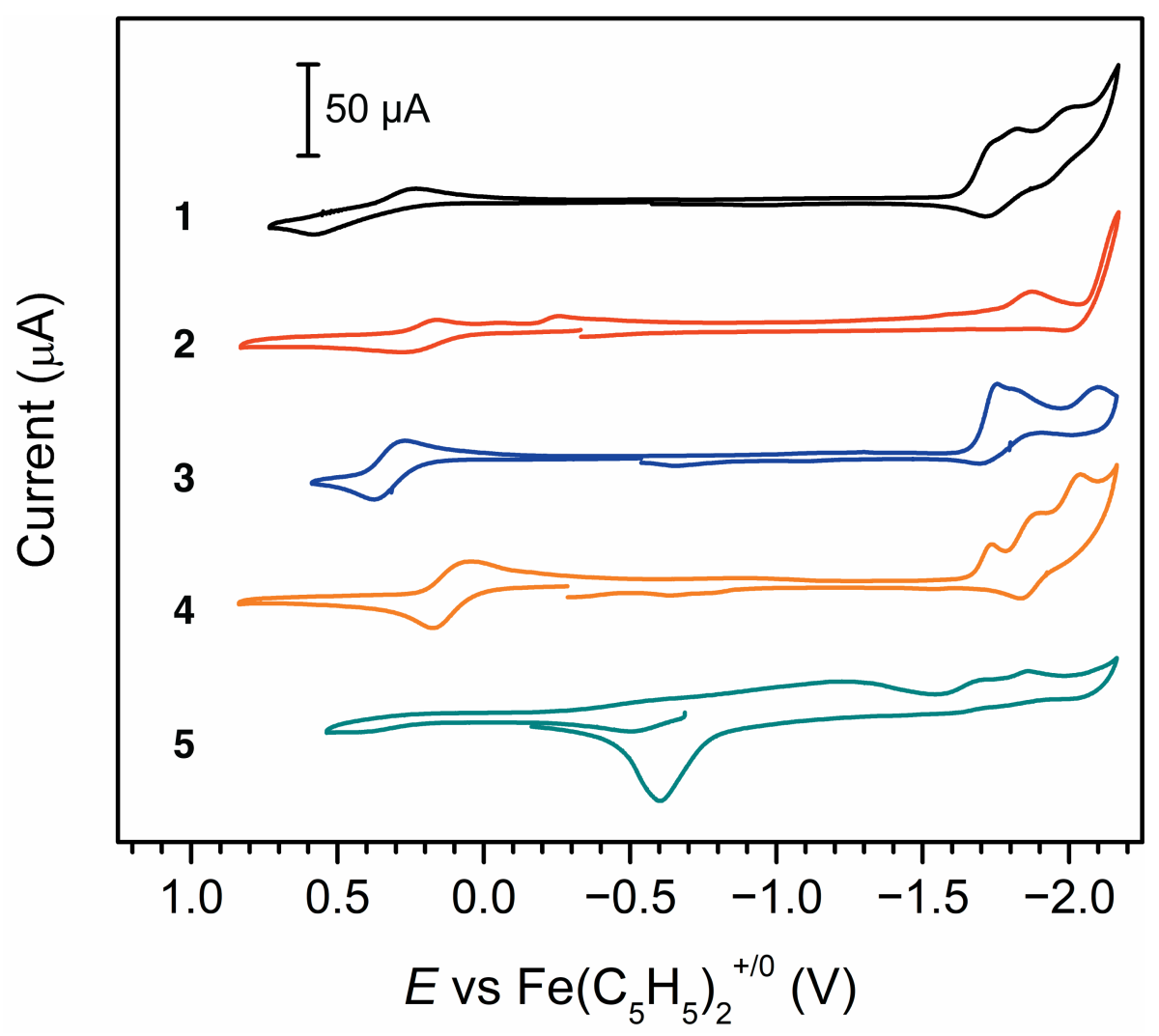

Figure S14. Cyclic voltammograms of complexes 1-5 in $\mathrm{N}_{2}$-saturated $\mathrm{CH}_{3} \mathrm{CN}$ solutions with 11 $\mathrm{M} \mathrm{H}_{2} \mathrm{O}$ and $0.1 \mathrm{M} \mathrm{NBu}_{4} \mathrm{PF}_{6}$ as the supporting electrolyte. All scans were performed at $0.1 \mathrm{~V} \mathrm{~s}^{-1}$, sweeping first to positive potentials 


\section{Cyclic Voltammograms in Mixed Acetonitrile-Water with $\mathrm{CO}_{2}$}

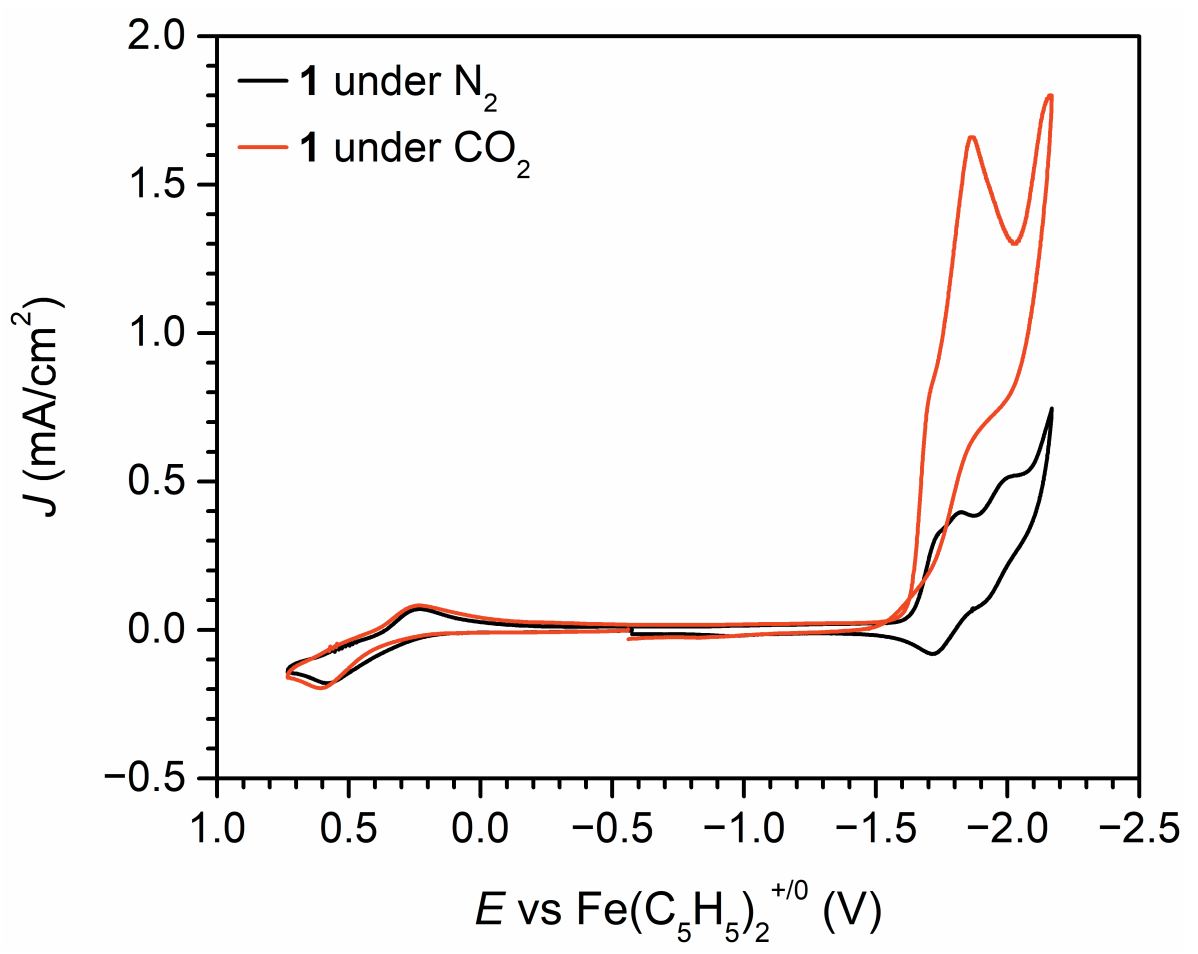

Figure S15. Cyclic voltammograms of 1 in $\mathrm{CH}_{3} \mathrm{CN}$ and $11 \mathrm{M} \mathrm{H}_{2} \mathrm{O}$, saturated with $\mathrm{N}_{2}$ (black) and $\mathrm{CO}_{2}$ (red), collected at a scan rate of $0.1 \mathrm{~V} / \mathrm{s}$, sweeping first to positive potentials. Data was obtained using a glassy carbon disk ( $3 \mathrm{~mm}$ dia.) working electrode, an $\mathrm{Ag} / \mathrm{AgNO}_{3}$ reference electrode, and a graphite counter electrode with $0.1 \mathrm{M} \mathrm{NBu}_{4} \mathrm{PF}_{6}$ as supporting electrolyte. 


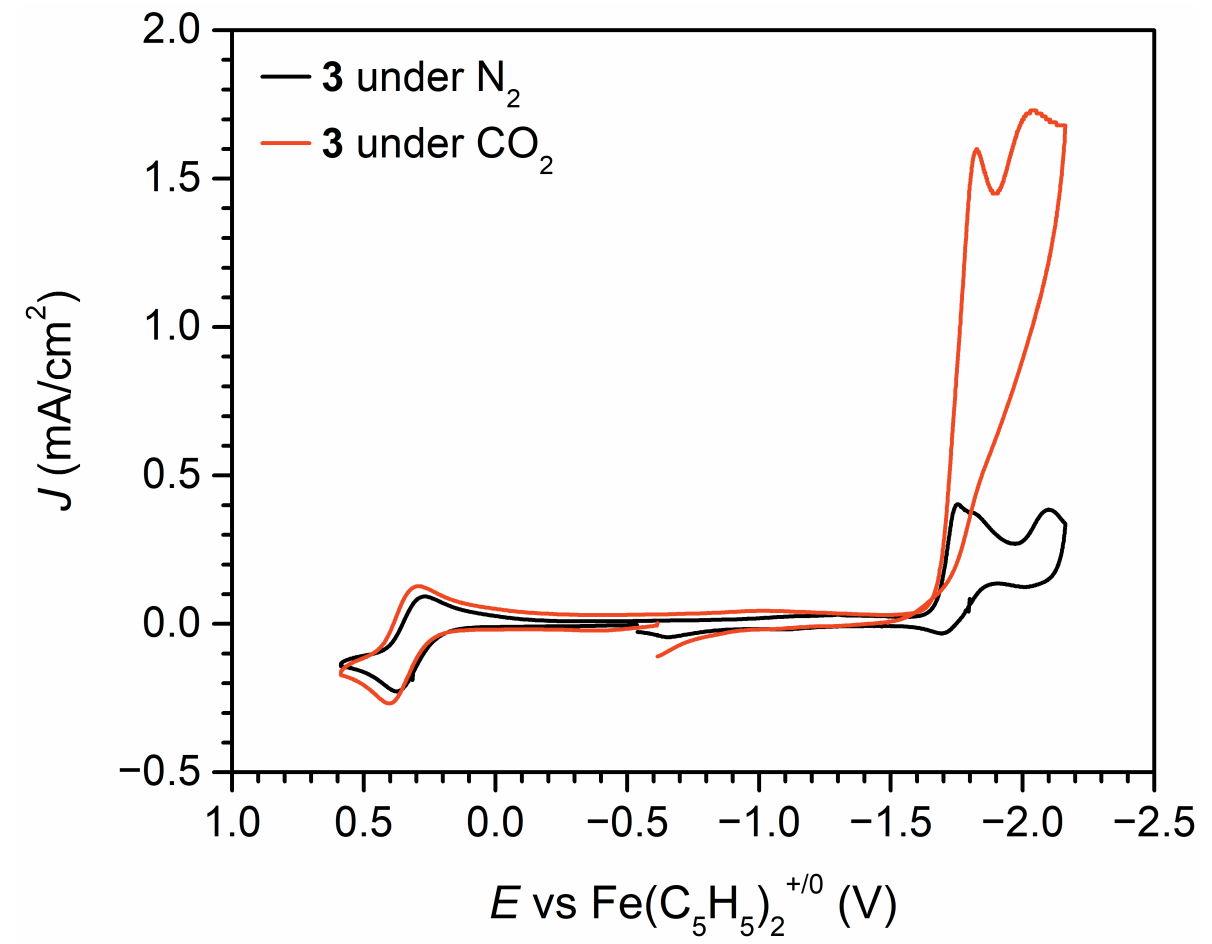

Figure S16. Cyclic voltammograms of 3 in $\mathrm{CH}_{3} \mathrm{CN}$ and $11 \mathrm{M} \mathrm{H}_{2} \mathrm{O}$, saturated with $\mathrm{N}_{2}$ (black) and $\mathrm{CO}_{2}$ (red), collected at a scan rate of $0.1 \mathrm{~V} / \mathrm{s}$, sweeping first to positive potentials. Data was obtained using a glassy carbon disk ( $3 \mathrm{~mm}$ dia.) working electrode, an $\mathrm{Ag} / \mathrm{AgNO}_{3}$ reference electrode, and a graphite counter electrode with $0.1 \mathrm{M} \mathrm{NBu}_{4} \mathrm{PF}_{6}$ as supporting electrolyte. 


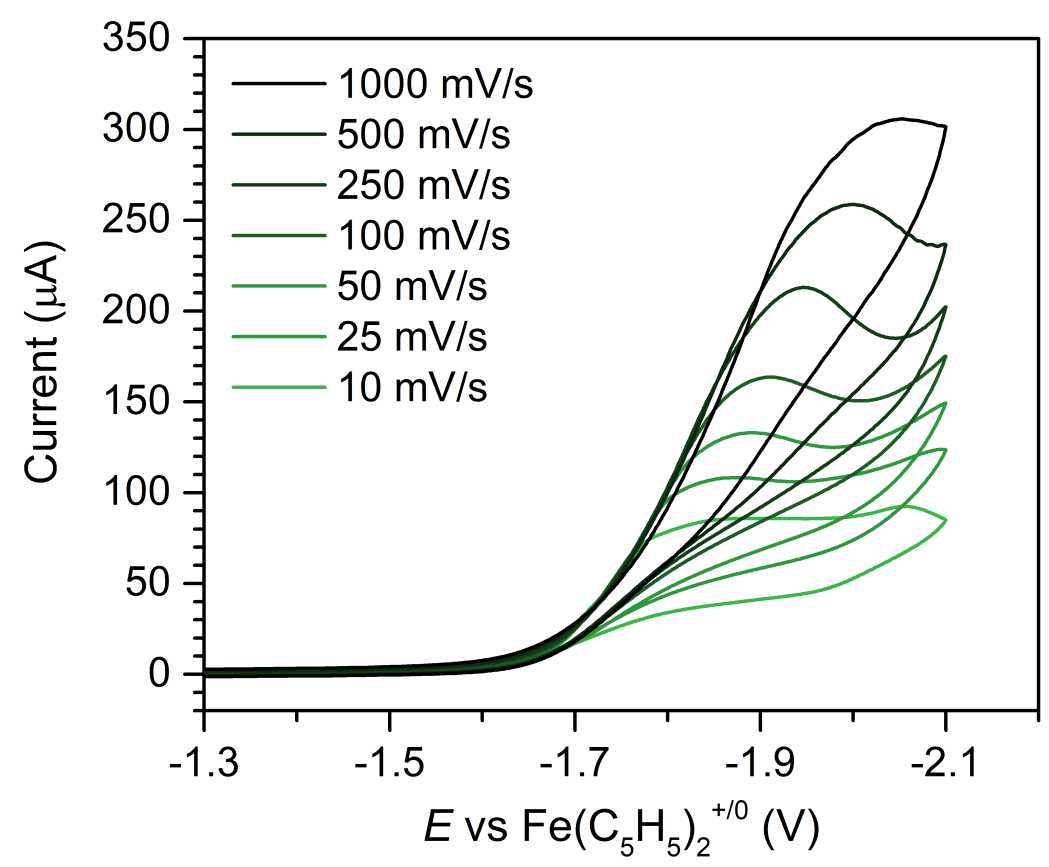

Figure S17. CVs of complex 4 in acetonitrile with $11 \mathrm{M} \mathrm{H}_{2} \mathrm{O}$, under $1 \mathrm{~atm}$ of $\mathrm{CO}_{2}$, measured with decreasing scan rates from $1000 \mathrm{mV} / \mathrm{s}$ to $10 \mathrm{mV} / \mathrm{s}$. As the scan rate is reduced, catalytic regeneration of $\mathbf{4}$ becomes competitive, leading to less pronounced "peaking" in the waveform. ${ }^{3}$

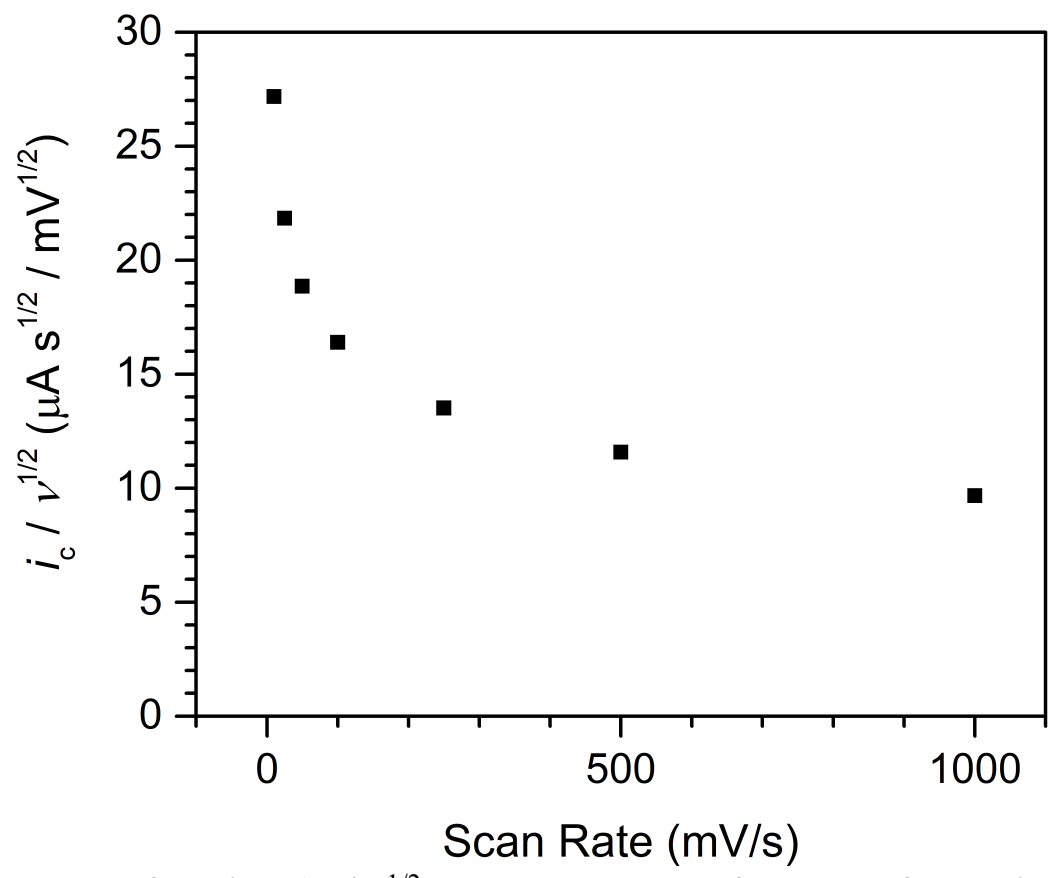

Figure S18. The current function $\left(i_{p} / v^{1 / 2}\right)$ versus scan rate for CVs of complex 4 in acetonitrile with $11 \mathrm{M} \mathrm{H}_{2} \mathrm{O}$, under $1 \mathrm{~atm}$ of $\mathrm{CO}_{2}$. The current function $\left(i_{\mathrm{c}} / v^{1 / 2}\right)$ significantly increases with the decrease in scan rate, indicative of catalysis. ${ }^{3}$ 


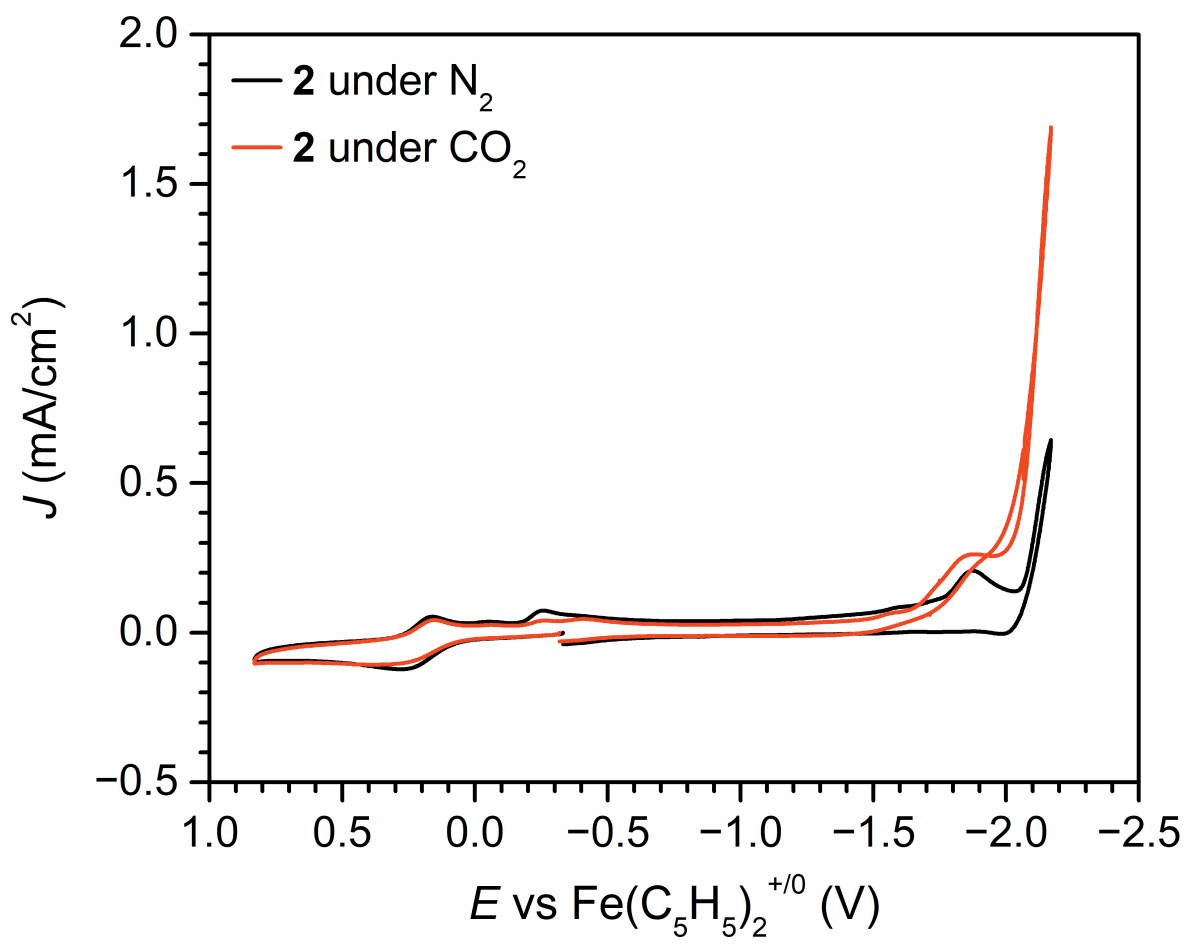

Figure S19. Cyclic voltammograms of 2 in $\mathrm{CH}_{3} \mathrm{CN}$ and $11 \mathrm{M} \mathrm{H}_{2} \mathrm{O}$, saturated with $\mathrm{N}_{2}$ (black) and $\mathrm{CO}_{2}$ (red), collected at a scan rate of $0.1 \mathrm{~V} / \mathrm{s}$, sweeping first to positive potentials. Data was obtained using a glassy carbon disk (3 mm dia.) working electrode, an $\mathrm{Ag} / \mathrm{AgNO}_{3}$ reference electrode, and a graphite counter electrode with $0.1 \mathrm{M} \mathrm{NBu}_{4} \mathrm{PF}_{6}$ as supporting electrolyte. 


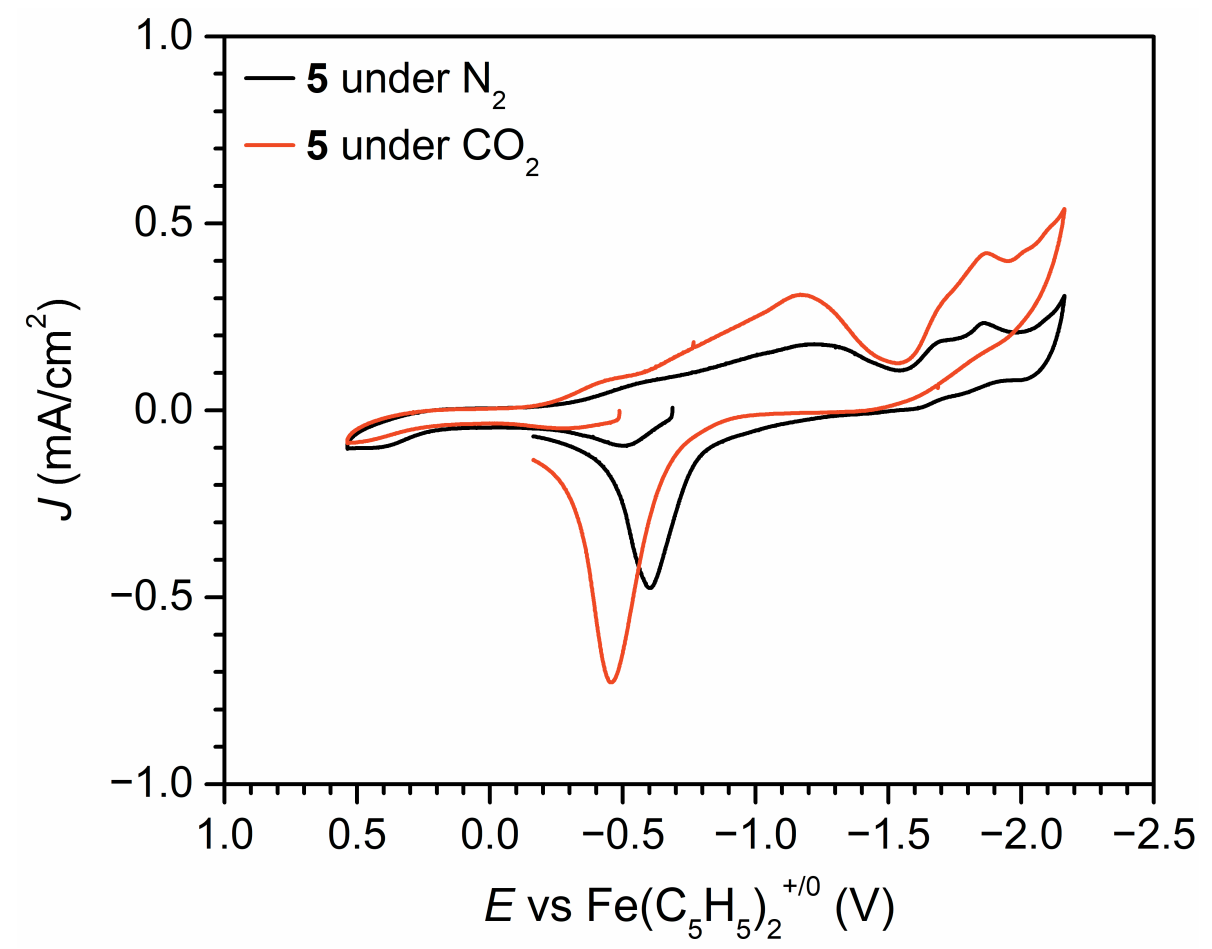

Figure S20. Cyclic voltammograms of 5 in $\mathrm{CH}_{3} \mathrm{CN}$ and $11 \mathrm{M} \mathrm{H}_{2} \mathrm{O}$, saturated with $\mathrm{N}_{2}$ (black) and $\mathrm{CO}_{2}$ (red), collected at a scan rate of $0.1 \mathrm{~V} / \mathrm{s}$. Data was obtained using a glassy carbon disk ( $3 \mathrm{~mm}$ dia.) working electrode, an $\mathrm{Ag} / \mathrm{AgNO}_{3}$ reference electrode, and a graphite counter electrode with $0.1 \mathrm{M} \mathrm{NBu}_{4} \mathrm{PF}_{6}$ as supporting electrolyte. 


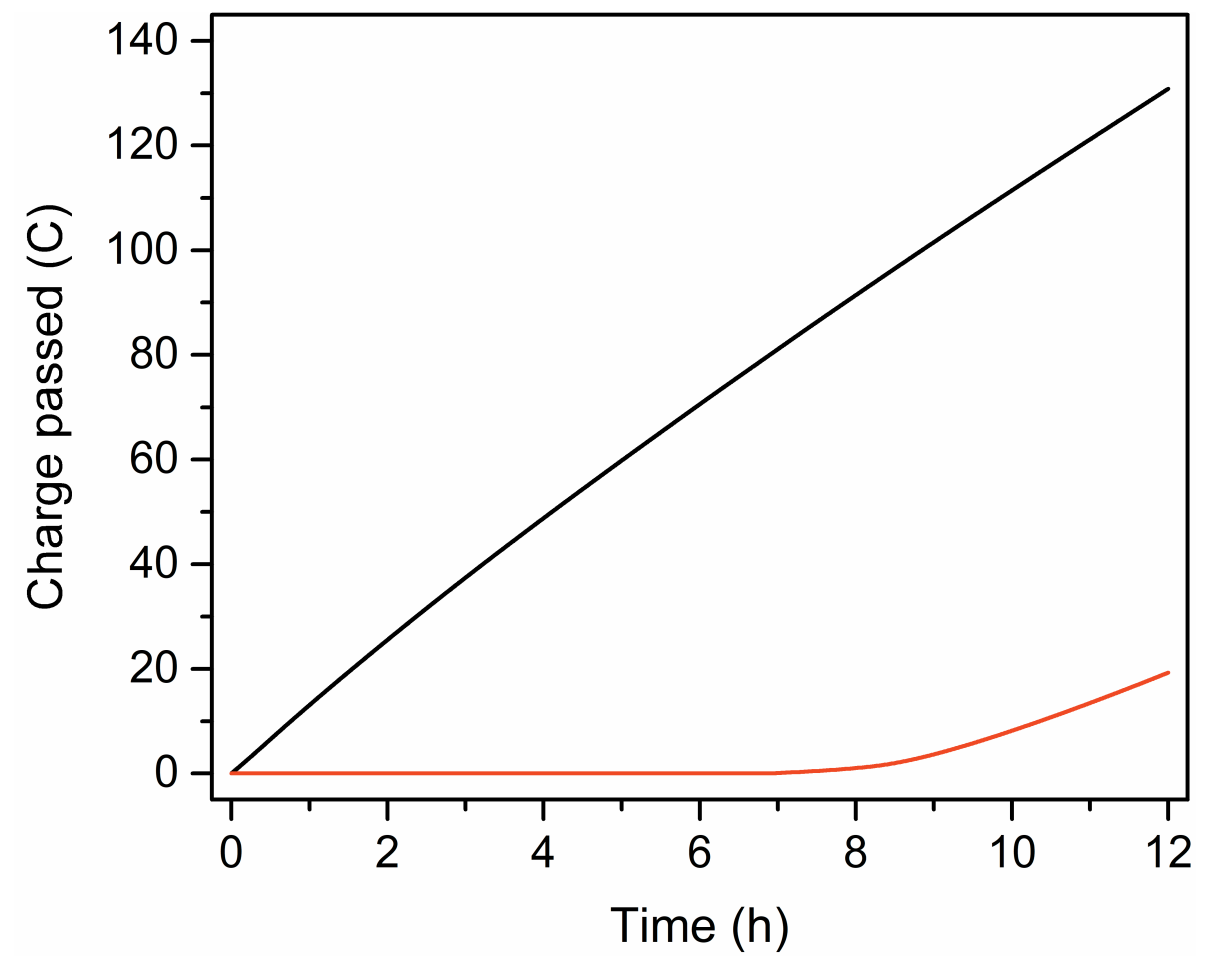

Figure S21. Charge buildup during controlled-potential electrolyses at $-1.91 \mathrm{~V}$ versus $\mathrm{Fe}\left(\mathrm{C}_{5} \mathrm{H}_{5}\right)_{2}{ }^{+/ 0}$, with $240 \mu \mathrm{M}$ of 4 (black) or $240 \mu \mathrm{M}$ of $\mathrm{Fe}\left(\mathrm{CF}_{3} \mathrm{SO}_{3}\right)_{2}$ (red). The activity of the bare glassy carbon electrode has been subtracted from the plotted data.

Table S3. Summary of controlled-potential electrolyses, without correcting for the reactivity of the glassy carbon electrode. ${ }^{a}$

\begin{tabular}{cccccc} 
& charge & charge equivalent ${ }^{b}$ of gas produced (C) & \multicolumn{2}{c}{ Faradaic efficiency (\%) } \\
compound & passed $(\mathrm{C})$ & $\mathrm{H}_{2}$ & $\mathrm{CO}$ & $\mathrm{H}_{2}$ & $\mathrm{CO}$ \\
none & $19 \pm 2$ & $18 \pm 2$ & $-^{c}$ & $98 \pm 1$ & $-^{c}$ \\
$\mathbf{1}$ & $47 \pm 2$ & $17 \pm 2$ & $6.0 \pm 0.1$ & $36 \pm 2$ & $19 \pm 2$ \\
$\mathbf{2}$ & $71 \pm 29$ & $46 \pm 21$ & $12 \pm 8$ & $65 \pm 3$ & $17 \pm 4$ \\
$\mathbf{3}$ & $31 \pm 15$ & $17 \pm 8$ & $5 \pm 1$ & $55 \pm 11$ & $16 \pm 4$ \\
$\mathbf{4}$ & $149 \pm 21$ & $31 \pm 4$ & $100 \pm 11$ & $21 \pm 3$ & $67 \pm 6$ \\
$\mathbf{5}$ & $88 \pm 7$ & $73 \pm 7$ & $0.6 \pm 0.1$ & $83 \pm 3$ & $0.7 \pm 0.1$ \\
$\mathbf{6}$ & $19 \pm 2$ & $19 \pm 2$ & $-^{c}$ & $100 \pm 1$ & $-^{c}$ \\
$\mathrm{Fe}\left(\mathrm{CF}_{3} \mathrm{SO}_{3}\right)_{2}$ & $38 \pm 2$ & $30 \pm 2$ & $-^{c}$ & $79 \pm 2$ & $-^{c}$ \\
$\mathbf{4}$, then & $19 \pm 3$ & $18 \pm 3$ & $-^{c}$ & $95 \pm 3$ & $-^{c}$ \\
rinsed & & & &
\end{tabular}

${ }^{a}$ Electrolysis conditions: $240 \mu \mathrm{M}$ of compound in a $70 \mathrm{~mL}$ solution of acetonitrile with $11 \mathrm{M} \mathrm{H}_{2} \mathrm{O}$, under $1 \mathrm{~atm}$ of $\mathrm{CO}_{2}$, with an applied potential at $-1.91 \mathrm{~V}$ for $12 \mathrm{~h}$. ${ }^{b}$ Moles of gas produced times two times Faraday's constant. $c_{-}$, below detection limit. 
Table S4. Summary of controlled-potential electrolyses at $-1.9 \mathrm{~V}$, subtracting background hydrogen evolution reactivity of the glassy carbon electrode. ${ }^{a}$

\begin{tabular}{|c|c|c|c|c|c|}
\hline \multirow[b]{2}{*}{ compound } & \multirow{2}{*}{$\begin{array}{c}\text { charge } \\
\text { passed (C) }\end{array}$} & \multicolumn{2}{|c|}{ charge equivalent ${ }^{b}$ of gas produced (C) } & \multicolumn{2}{|c|}{ Faradaic efficiency (\%) } \\
\hline & & $\mathrm{H}_{2}$ & $\mathrm{CO}$ & $\mathrm{H}_{2}$ & $\mathrm{CO}$ \\
\hline 1 & $28 \pm 1$ & $0^{c}$ & $6.0 \pm 0.1$ & $0^{c}$ & $22 \pm 1$ \\
\hline 2 & $52 \pm 29$ & $28 \pm 21$ & $12 \pm 8$ & $53 \pm 11$ & $24 \pm 2$ \\
\hline 3 & $13 \pm 15$ & $0^{c}$ & $5 \pm 1$ & $0^{c}$ & $38 \pm 23$ \\
\hline 4 & $130 \pm 21$ & $13 \pm 4$ & $100 \pm 11$ & $10 \pm 3$ & $81 \pm 11$ \\
\hline 5 & $69 \pm 8$ & $55 \pm 8$ & $0.6 \pm 0.1$ & $80 \pm 3$ & $0.9 \pm 0.1$ \\
\hline 6 & $0^{c}$ & $0^{c}$ & $-^{d}$ & $0^{c}$ & $-^{d}$ \\
\hline $\mathrm{Fe}\left(\mathrm{CF}_{3} \mathrm{SO}_{3}\right)_{2}$ & $19 \pm 2$ & $12 \pm 2$ & $-^{d}$ & $63 \pm 2$ & $-^{d}$ \\
\hline $\begin{array}{l}4 \text {, then } \\
\text { rinsed }\end{array}$ & $0^{c}$ & $0^{c}$ & $-^{d}$ & $0^{c}$ & $-^{d}$ \\
\hline
\end{tabular}

${ }^{a}$ Electrolysis conditions: $240 \mu \mathrm{M}$ of compound in a $70 \mathrm{~mL}$ solution of acetonitrile with $11 \mathrm{M} \mathrm{H}_{2} \mathrm{O}$, under $1 \mathrm{~atm}$ of $\mathrm{CO}_{2}$, with an applied potential at $-1.91 \mathrm{~V}$ for $12 \mathrm{~h} .{ }^{b}$ Moles of gas produced times two times Faraday's constant. ${ }^{c}$ Equal, within error, to the activity of bare glassy carbon electrode. ${ }^{d}$-, below detection limit.

\section{${ }^{1}$ H NMR Analysis of Electrolysis Solutions}

Our protocol for ${ }^{1} \mathrm{H}$ NMR analysis of liquid $\mathrm{CO}_{2}$ reduction products in the electrolyte solution derives from one used by Kang and coworkers. ${ }^{4}$ After electrolysis, a $1500 \mu \mathrm{L}$ aliquot of the electrolyte solution was taken and to it was added $750 \mu \mathrm{L}$ of $\mathrm{CD}_{3} \mathrm{CN}$ and $25 \mu \mathrm{L}$ of concentrated aqueous $\mathrm{HCl}$ ( $38 \%$ by weight). The acid was added to liberate any formate from the $\mathrm{Fe}$ ion that may have formed during electrolysis. In all cases, no resonances attributable to formic acid, formaldehyde, or methanol were observed in the ${ }^{1} \mathrm{H}$ NMR. Resonances were observed for the ${ }^{+} \mathrm{NBu}_{4}$ cation, as well as polypyridine resonances resulting from the acidic workup. 
Table S5. Faradaic efficiencies of Fe-containing electrocatalysts for $\mathrm{CO}_{2}$ reduction.

\begin{tabular}{|c|c|c|c|c|c|c|c|}
\hline \multirow[b]{2}{*}{ compound } & \multirow[b]{2}{*}{ electrolysis conditions $^{a}$} & \multicolumn{6}{|c|}{ Faradaic efficiency (\%) } \\
\hline & & applied potential (V) & $\mathrm{CO}$ & $\mathrm{HCOO}^{-}$ & $\mathrm{C}_{2} \mathrm{O}_{4}{ }^{2-}$ & $\mathrm{H}_{2}$ & ref \\
\hline 4 & $11 \mathrm{M} \mathrm{H}_{2} \mathrm{O}$ in $\mathrm{CH}_{3} \mathrm{CN}$ & $-1.91 \mathrm{~V}$ vs $\left[\mathrm{Fe}\left(\mathrm{C}_{5} \mathrm{H}_{5}\right)_{2}\right]^{+/ 0}$ & $81 \pm 11$ & 0 & $-^{b}$ & $11 \pm 3$ & this work \\
\hline $\mathrm{FeTPP}^{c}$ & $1 \mathrm{M} \mathrm{CF}_{3} \mathrm{CH}_{2} \mathrm{OH}$ in DMF & $-2.15 \mathrm{~V}^{d} \mathrm{vs}\left[\mathrm{Fe}\left(\mathrm{C}_{5} \mathrm{H}_{5}\right)_{2}\right]^{+/ 0}$ & 100 & 0 & 0 & 0 & 5 \\
\hline $\mathrm{FeTPP}^{c}$ & $1 \mathrm{M} \mathrm{PhOH}$ in DMF & $-2.15 \mathrm{~V}^{d}$ vs $\left[\mathrm{Fe}\left(\mathrm{C}_{5} \mathrm{H}_{5}\right)_{2}\right]^{+/ 0}$ & 94 & 0 & 0 & 0 & 5 \\
\hline $\mathrm{FeTPP}^{c}$ & $0.1 \mathrm{M} \mathrm{AcOH}$ & $-2.15 \mathrm{~V}^{d}$ vs $\left[\mathrm{Fe}\left(\mathrm{C}_{5} \mathrm{H}_{5}\right)_{2}\right]^{+/ 0}$ & 31 & 0 & 0 & 0 & 5 \\
\hline $\mathrm{FeTDHPP}^{e}$ & $2 \mathrm{M} \mathrm{H}_{2} \mathrm{O}$ in $\mathrm{DMF}$ & $-1.85 \mathrm{~V}^{d}$ vs $\left[\mathrm{Fe}\left(\mathrm{C}_{5} \mathrm{H}_{5}\right)_{2}\right]^{+/ 0}$ & 94 & $-{ }^{b}$ & $-{ }^{b}$ & 6 & 6 \\
\hline $\mathrm{Fe}\left(p-\mathrm{NMe}_{3}\right)_{4} \mathrm{TPP}^{f}$ & $\begin{array}{c}\text { pH } 6.7 \text { unbuffered aqueous } \\
\text { solution }\end{array}$ & $-0.97 \mathrm{~V}$ vs SHE & 90 & 0.7 & 0.5 & 7 & 7 \\
\hline $\mathrm{Fe}\left(p-\mathrm{NMe}_{3}\right)_{4} \mathrm{TPP}^{f}$ & $\begin{array}{c}\text { pH } 6.7 \text { unbuffered aqueous } \\
\text { solution }\end{array}$ & $-0.86 \mathrm{~V}$ vs SHE & $98-100$ & $-^{b}$ & $-^{b}$ & $-^{b}$ & 7 \\
\hline $\mathrm{Fe}\left(p-\mathrm{NMe}_{3}\right)_{4} \mathrm{TPP}^{f}$ & pH 6.7 phosphate buffer & $-0.86 \mathrm{~V}$ vs SHE & 50 & $-^{b}$ & $-^{b}$ & 50 & 7 \\
\hline $\mathrm{Fe}\left(\mathrm{C}_{6} \mathrm{~F}_{5}\right)_{2} \mathrm{DHDPP}^{g}$ & $3 \mathrm{M} \mathrm{PhOH}$ in DMF & $-1.77 \mathrm{~V}^{d}$ vs $\left[\mathrm{Fe}\left(\mathrm{C}_{5} \mathrm{H}_{5}\right)_{2}\right]^{+/ 0}$ & $100 \pm 10$ & $-^{b}$ & $-^{b}$ & $<1$ & 8 \\
\hline $\mathrm{Fe}\left(o-\mathrm{NMe}_{3}\right)_{4} \mathrm{TPP}^{h}$ & $\begin{array}{c}0.1 \mathrm{M} \mathrm{H}_{2} \mathrm{O} \text { and } 3 \mathrm{M} \mathrm{PhOH} \\
\text { in DMF }\end{array}$ & $-1.65 \mathrm{~V}^{d} \mathrm{vs}\left[\mathrm{Fe}\left(\mathrm{C}_{5} \mathrm{H}_{5}\right)_{2}\right]^{+/ 0}$ & 93 & $--^{b}$ & $-{ }^{b}$ & 0 & 9 \\
\hline $\mathrm{Fe}($ dophen $)(\mathrm{MeIm})_{2}{ }^{i}$ & $1.23 \mathrm{M} \mathrm{CH}_{3} \mathrm{OH}$ in DMF & $-2.00 \mathrm{~V}$ vs $\left[\mathrm{Fe}\left(\mathrm{C}_{5} \mathrm{H}_{5}\right)_{2}\right]^{+/ 0}$ & 30 & 52 & 11 & 0 & 10 \\
\hline $\mathrm{Fe}($ dophen $)(\mathrm{MeIm})_{2}{ }^{i}$ & $1.23 \mathrm{M} \mathrm{CF}_{3} \mathrm{CH}_{2} \mathrm{OH}$ in $\mathrm{DMF}$ & $-2.00 \mathrm{~V}$ vs $\left[\mathrm{Fe}\left(\mathrm{C}_{5} \mathrm{H}_{5}\right)_{2}\right]^{+/ 0}$ & 31 & 53 & 9 & 0 & 10 \\
\hline $\mathrm{Fe}($ dophen $)(\mathrm{MeIm})_{2}{ }^{i}$ & $1.23 \mathrm{M} \mathrm{CH}_{3} \mathrm{OH}$ in DMSO & $-2.00 \mathrm{~V}$ vs $\left[\mathrm{Fe}\left(\mathrm{C}_{5} \mathrm{H}_{5}\right)_{2}\right]^{+/ 0}$ & 26 & 66 & 6 & 0 & 10 \\
\hline $\mathrm{Fe}($ dophen $)(\mathrm{MeIm})_{2}{ }^{i}$ & $\begin{array}{c}1.23 \mathrm{M} \mathrm{CF}_{3} \mathrm{CH}_{2} \mathrm{OH} \text { in } \\
\mathrm{DMSO}\end{array}$ & $-2.00 \mathrm{~V}$ vs $\left[\mathrm{Fe}\left(\mathrm{C}_{5} \mathrm{H}_{5}\right)_{2}\right]^{+/ 0}$ & 30 & 65 & 3 & 0 & 10 \\
\hline$\left[\mathrm{Fe}(\mathrm{L}) \mathrm{Cl}_{2}\right]^{+j}$ & $\mathrm{DMF}^{k}$ & $-1.70 \mathrm{~V}^{l}$ vs $\left[\mathrm{Fe}\left(\mathrm{C}_{5} \mathrm{H}_{5}\right)_{2}\right]^{+/ 0}$ & 0 & $75-80 \%$ & - & 0 & 11 \\
\hline$\left[\mathrm{Fe}_{4} \mathrm{~N}(\mathrm{CO})_{12}\right]^{-}$ & pH $6.5 \mathrm{KHCO}_{3}$ buffer & $-1.20 \mathrm{~V}$ vs SCE & 0 & $96 \pm 2$ & 0 & $2 \pm 1$ & 12 \\
\hline $\begin{array}{l}{ }^{a} \text { performed under } 1 \text { atr } \\
\text { saturated calomel elect } \\
{ }^{{ }^{2}} \mathrm{H}_{2} \mathrm{TDHPP}=2,2^{\prime}, 2^{\prime \prime}, 2 \\
\text { trimethylbenzenaminiu } \\
\text { (porphyrin-5,10,15,20- } \\
{ }^{j} \mathrm{~L}=(2 E, 12 E)-2,13-\mathrm{din} \\
{\left[\mathrm{Fe}\left(\mathrm{C}_{5} \mathrm{H}_{5}\right)_{2}\right]^{+/ 0} \text { redox co }}\end{array}$ & $\begin{array}{l}\text { of } \mathrm{CO}_{2} .{ }^{b}-\text {, not determined o } \\
\text { le }(\mathrm{SCE}=0.24 \mathrm{~V} \text { vs } \mathrm{SHE})^{13}, \\
\text { (porphyrin-5,10,15,20-tetray } \\
{ }^{8} \mathrm{H}_{2}\left(\mathrm{C}_{6} \mathrm{~F}_{5}\right)_{2} \mathrm{DHDPP}=2,2 \\
\text { rayl)tetrakis } \mathrm{N}, \mathrm{N}, \mathrm{N} \text {-trimethy } \\
\text { hyl-3,6,9,12-tetraaza-1 }(2,6)-1 \\
\text { le }\left(\left[\mathrm{Fe}\left(\mathrm{C}_{5} \mathrm{H}_{5}\right)_{2}\right]^{+/ 0}=0.45 \mathrm{~V} \mathrm{v}\right.\end{array}$ & $\begin{array}{l}\text { ported. }{ }^{c} \mathrm{H}_{2} \mathrm{TPP}=(5,10,15, \\
\text { a referencing against the }[\mathrm{F} \\
\text { trakis(benzene-1,3-diol). } \\
0,20 \text {-bis(perfluorophenyl)p } \\
\text { nzenaminium). }{ }^{i} \mathrm{H}_{2} \text { dophen }= \\
\text { idinacyclotridecaphane- } 2,12 \\
\left.\mathrm{CE} \text { in DMF solution }{ }^{14}\right) .\end{array}$ & $\begin{array}{l}\text { tetraphen } \\
\left.\left.\mathrm{H}_{5}\right)_{2}\right]^{+/ 0} \mathrm{re} \\
\text {-NMe })_{4} \\
\text { hyrin-5,1 } \\
\text {-bis(2-hy } \\
\text { ene. kno }\end{array}$ & $\begin{array}{l}\text { rphyrin) } \\
\text { couple } \\
=4,4^{\prime}, 4 \\
\text { yl)bis(be } \\
\text { xyphenyl }\end{array}$ & $\begin{array}{l}\text { verted } \\
\left.\left.{ }_{5} \mathrm{H}_{5}\right)_{2}\right]^{+} \\
\text {(porph } \\
-1,3-\mathrm{di} \\
\text {-phena }\end{array}$ & $\begin{array}{l}\text { HE by } \\
5 \mathrm{~V} \text { vs } \\
10,15,2( \\
\mathrm{H}_{2}(o-\mathrm{NN} \\
\text { ne; MeI } \\
\text { SCE by }\end{array}$ & $\begin{array}{l}\text { rencing age } \\
\text { MF solutio } \\
\text { tetrakis }(N, \\
=2,2^{\prime}, 2^{\prime \prime} \\
\text { ethylimidaz } \\
\text { cing agains }\end{array}$ \\
\hline
\end{tabular}




\section{Electrochemical Characterization of Electrode Postelectrolysis}

After a $12 \mathrm{~h}$ electrolysis of 4 in $\mathrm{CO}_{2}$-saturated $\mathrm{CH}_{3} \mathrm{CN}$ with $11 \mathrm{M} \mathrm{H}_{2} \mathrm{O}$, the electrolyte solution in the working electrode compartment was removed using a cannula, while keeping the electrolysis cell under an atmosphere of argon. The working electrode and cell chamber were washed with anhydrous, deaerated $\mathrm{CH}_{3} \mathrm{CN}(3 \times \sim 70 \mathrm{~mL})$ to remove traces of the original electrolyte solution. Electrochemical characterization of the electrode was subsequently performed on a fresh batch of degassed electrolyte solution, which was introduced with a cannula.
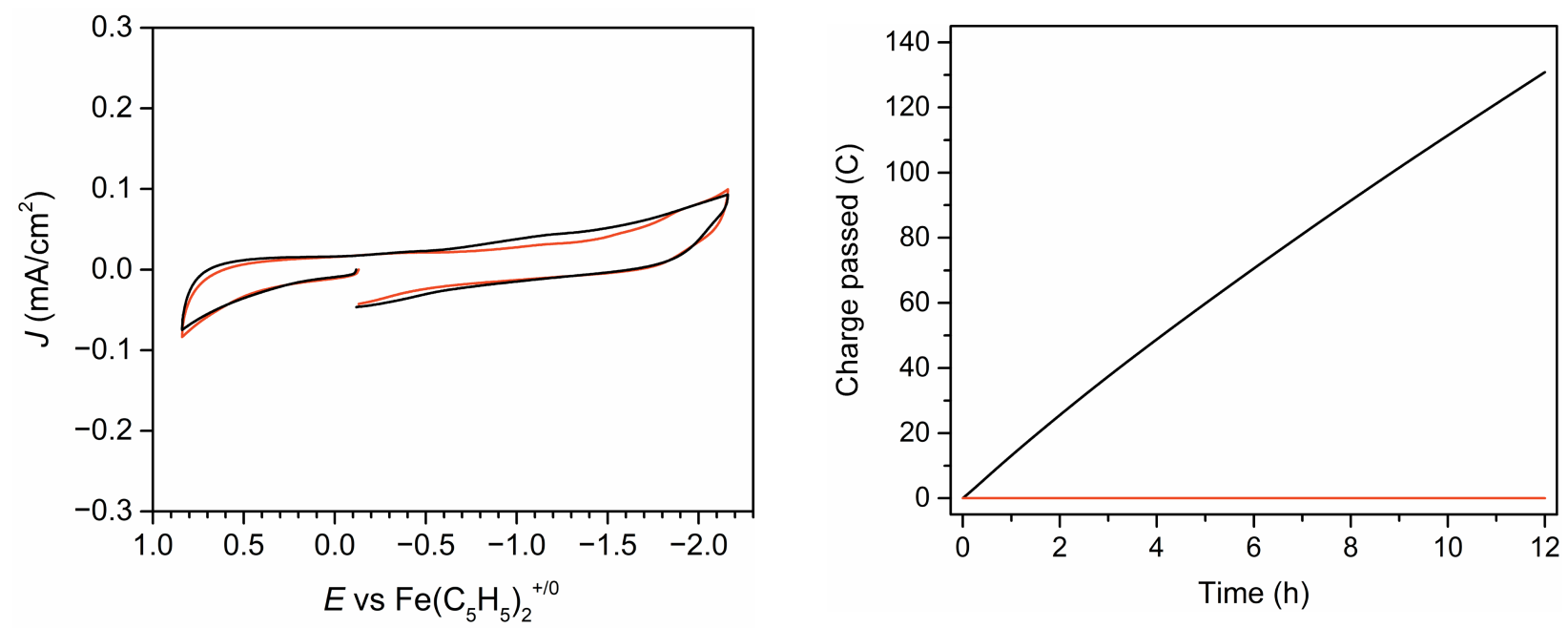

Figure S22. Left: $\mathrm{CVs}$ in $\mathrm{CO}_{2}$-saturated $\mathrm{CH}_{3} \mathrm{CN}$ with $11 \mathrm{M} \mathrm{H}_{2} \mathrm{O}$ of a polished glassy carbon electrode (black) and of a rinsed electrode (red) after a 12-h electrolysis with 4. Right: Charge buildup during controlled-potential electrolysis of at $-1.91 \mathrm{~V}$ versus $\mathrm{Fe}\left(\mathrm{C}_{5} \mathrm{H}_{5}\right)_{2}{ }^{+/ 0}$, with $240 \mu \mathrm{M}$ of 4 (black). The electrode was rinsed, then another electrolysis experiment was performed on fresh electrolyte (red). The activity of the bare glassy carbon electrode has been subtracted from the plotted data. 
SEM and EDX Analysis of Electrode Postelectrolysis

After a $12 \mathrm{~h}$ electrolysis of 4 in $\mathrm{CO}_{2}$-saturated $4: 1 \mathrm{CH}_{3} \mathrm{CN} / \mathrm{H}_{2} \mathrm{O}$, the electrolysis cell was disassembled. The glassy carbon working electrode was gently rinsed with $3 \times \sim 1 \mathrm{~mL}$ of $\mathrm{CH}_{3} \mathrm{CN}$ and then imaged by scanning electron microscopy (SEM). SEM images were taken using a Zeiss Ultra $55 \mathrm{SEM}$ at $15 \mathrm{kV}$. Chemical characterization of the surface was performed using energydispersive X-ray spectroscopy (EDX) using a Bruker Nano XFlash Detector 5030.
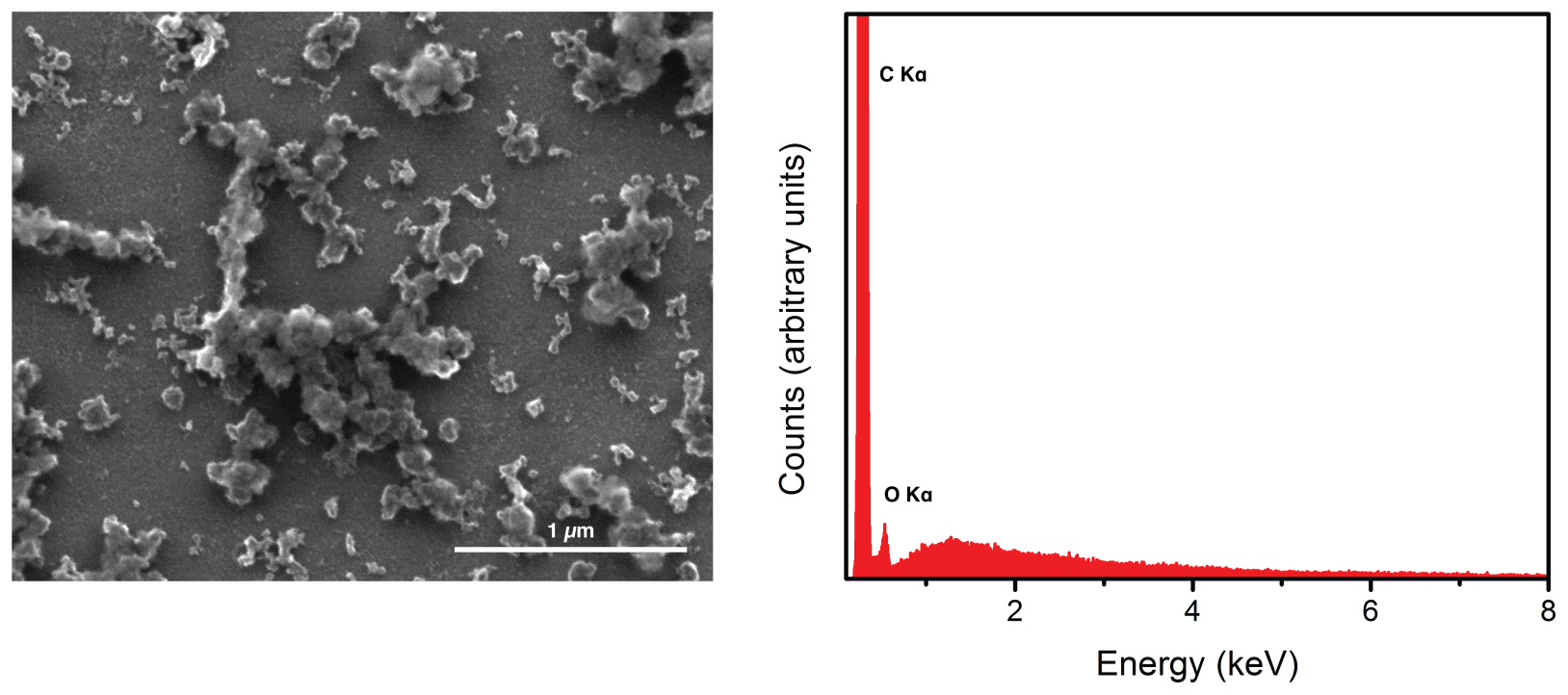

Figure S23. SEM (left) and EDX spectrum (right) of a glassy carbon electrode after a 12-h electrolysis with 4 in $\mathrm{CH}_{3} \mathrm{CN}$ with $11 \mathrm{M} \mathrm{H}_{2} \mathrm{O}$. The absence of $\mathrm{Fe} \mathrm{K}_{\alpha}(c a .6 .4 \mathrm{keV})$ and $\mathrm{K}_{\beta}(c a .7 .1$ $\mathrm{keV}$ ) lines suggests the lack of Fe-containing adsorbates on the electrode. 


\section{Foot-of-the-Wave Analyses (FOWA)}

To provide rate comparisons, the cyclic voltammograms for complexes 1-5 were analyzed using the FOWA method described by Costentin and Savéant. ${ }^{15}$ The specific treatment of FOWA depends on the mechanism for catalysis. Since we currently lack such mechanistic detail, we opted to apply the following generalized treatment:

$$
\frac{i}{i_{p}}=\frac{4.48 \sqrt{\frac{R T}{F v} k_{1}}}{1+\exp \left[\frac{F}{R T}\left(E-E_{1 / 2}^{0}\right)\right]}
$$

where $i$ is the current in the voltammogram, normalized by the current $i_{\mathrm{p}}$ of a reversible oneelectron redox couple. $R$ is the gas constant, $T$ is the temperature, $F$ is the Faraday constant, and $v$ is the scan rate. $E$ is the applied potential, and $E^{\circ}{ }_{1 / 2}$ is the potential required to reach half of the catalytic plateau current. In the CVs of complexes 1-4 in acetonitrile with $11 \mathrm{M} \mathrm{H}_{2} \mathrm{O}$ and under 1 atm of $\mathrm{CO}_{2}$, the cathodic currents did not reach the ideal plateau shape. In this case, $E^{\circ}{ }_{1 / 2}$ was estimated as the potential required to reach half of the peak/limiting current. $k_{1}$ is the rate constant of the first elementary step after reversible electron transfer. The normalized current $i / i_{\mathrm{p}}$ was plotted versus $\frac{1}{1+\exp \left[\frac{F}{R T}\left(E-E_{1 / 2}^{0}\right)\right]}$, and the foot-of-the-wave was fitted with a linear fit. These plots are shown in Figures S24-27. The slopes of the fit are $4.48 \sqrt{\frac{R T}{F v} k_{1}}$, allowing to solve for $k_{1}$ for each complex.

Using $k_{1}$, the TOF - potential relationship is then given by the following equation, which was used to derive Figure S28.

$$
T O F=\frac{k_{1}}{1+\exp \left[\frac{F}{R T}\left(E-E_{1 / 2}^{0}\right)\right]}
$$




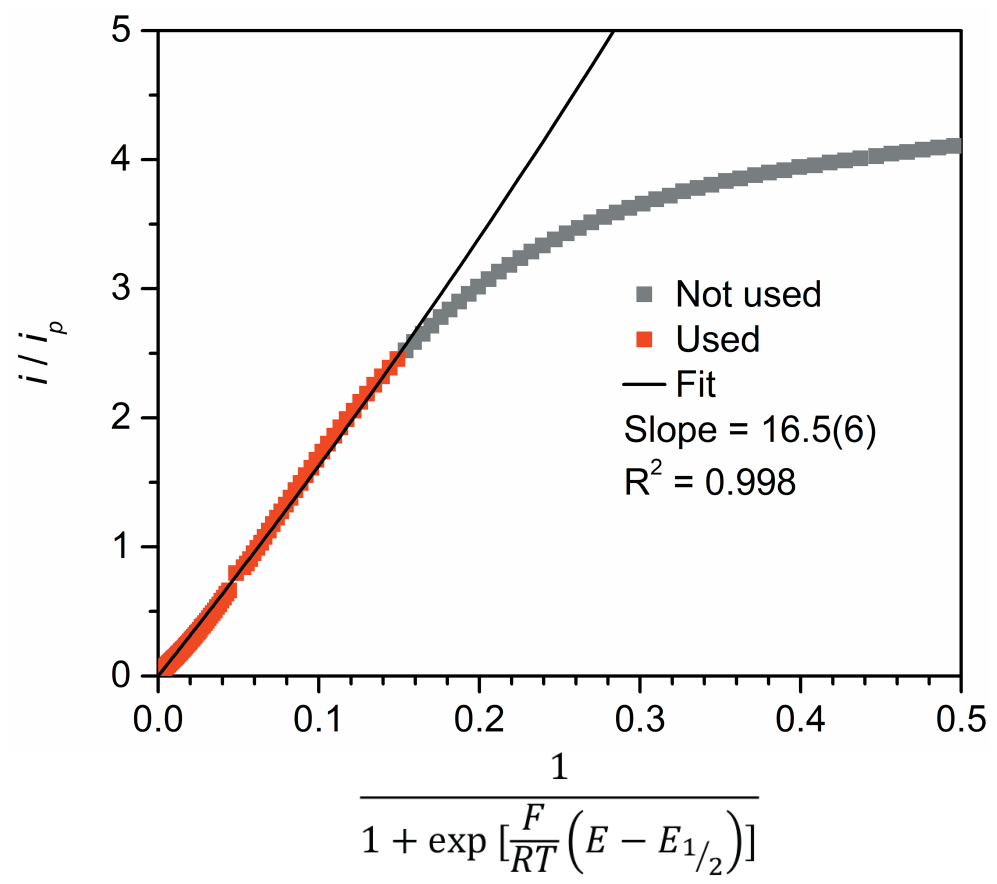

Figure S24. FOWA fit of a voltammogram of 1 in a $\mathrm{CO}_{2}$-saturated acetonitrile solution with $\left[\mathrm{H}_{2} \mathrm{O}\right]$ $=11 \mathrm{M}$.

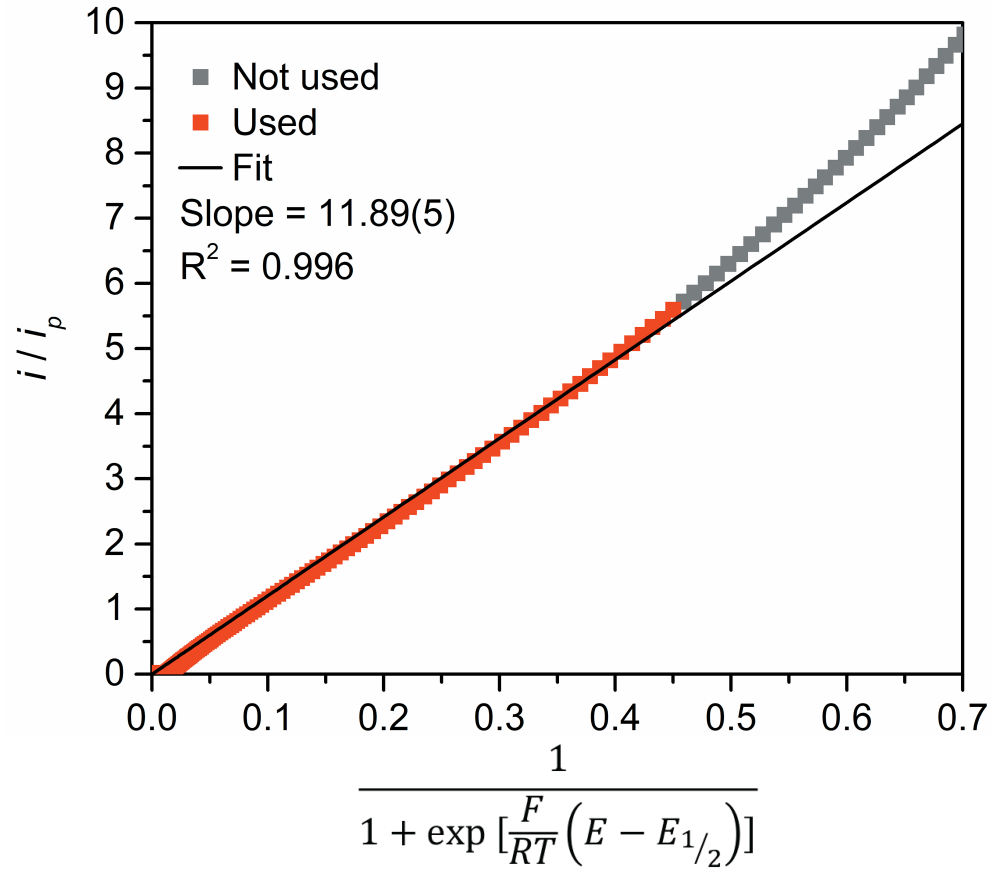

Figure S25 FOWA fit of a voltammogram of 2 in a $\mathrm{CO}_{2}$-saturated acetonitrile solution with $\left[\mathrm{H}_{2} \mathrm{O}\right]$ $=11 \mathrm{M}$. 


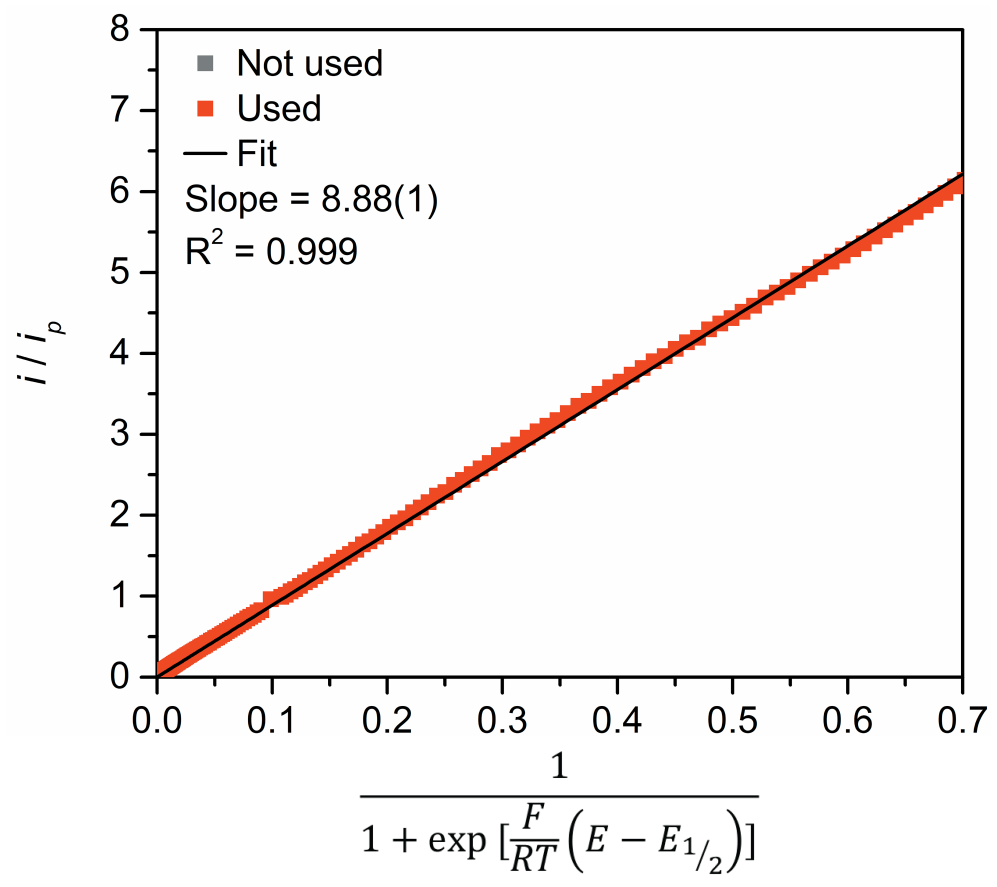

Figure S26. FOWA fit of a voltammogram of 3 in a $\mathrm{CO}_{2}$-saturated acetonitrile solution with $\left[\mathrm{H}_{2} \mathrm{O}\right]$ $=11 \mathrm{M}$.

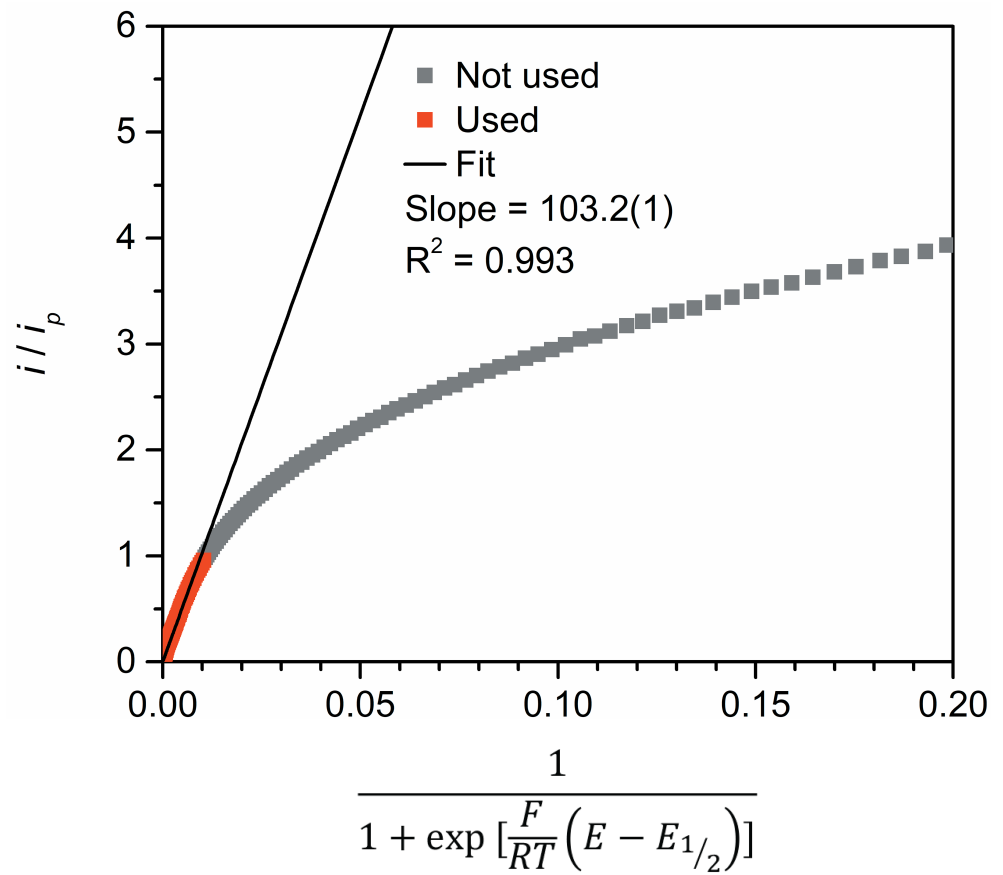

Figure S27. FOWA fit of a voltammogram of 4 in a $\mathrm{CO}_{2}$-saturated acetonitrile solution with $\left[\mathrm{H}_{2} \mathrm{O}\right]$ $=11 \mathrm{M}$. 


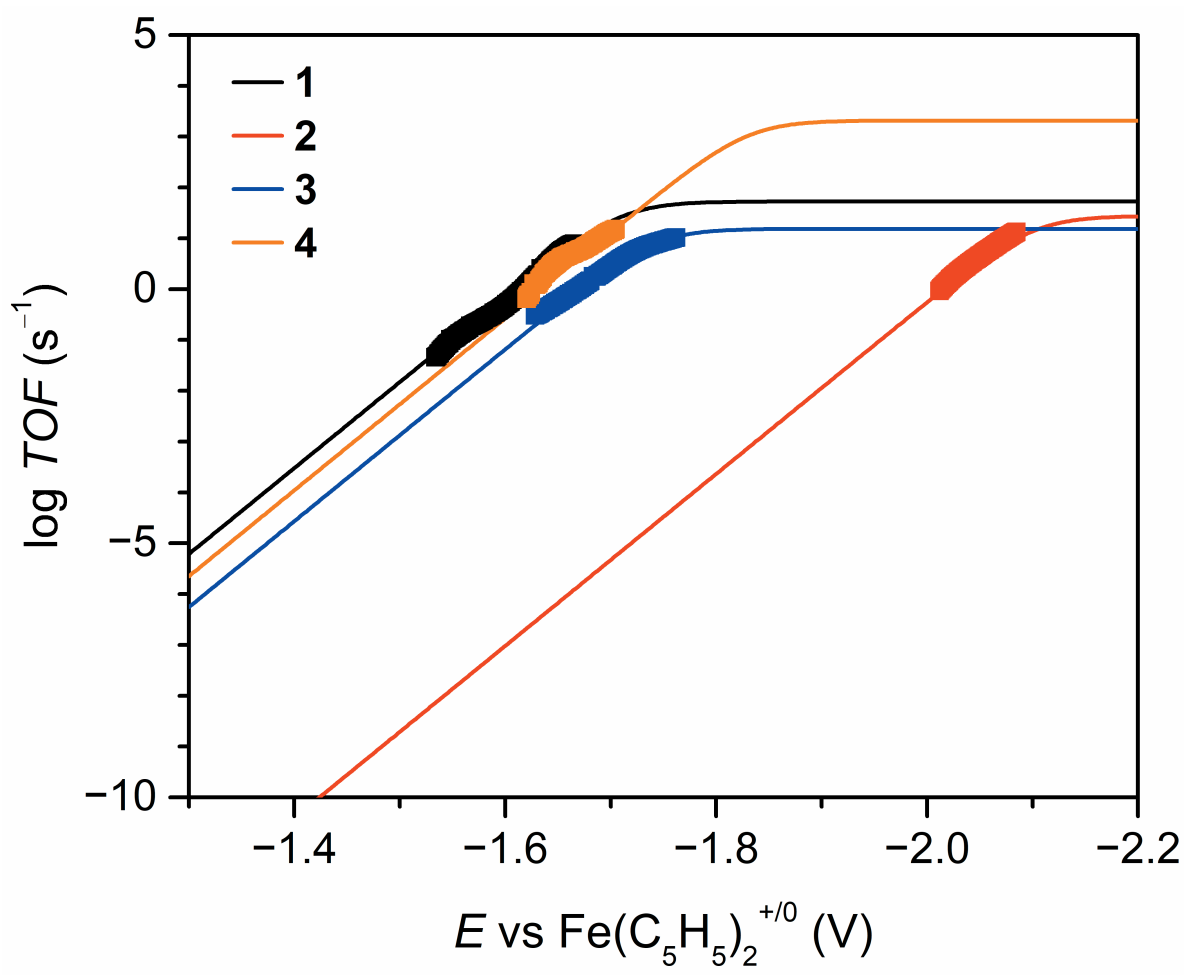

Figure S28. Logarithmic TOF versus potential plot of 1 (black), 2 (red), 3 (blue), and $\mathbf{4}$ (orange). Solid squares indicate experimental data used in FOWA to derive the log $\mathrm{TOF}$-potential relationship (lines). 


\section{References}

(1) Ünal, E. A.; Wiedemann, D.; Seiffert, J.; Boyd, J. P.; Grohmann, A. Efficient Synthesis of Pentakis- and Tris(Pyridine) Ligands. Tet. Lett. 2012, 53, 54-55.

Chen, L.; Su, X.-J.; Jurss, J. W. Selective Alkane C-H Bond Oxidation Catalyzed by a Non-Heme Iron Complex Featuring a Robust Tetradentate Ligand. Organometallics 2018, 37, 4535-4539.

Zanello, P.; Nervi, C.; Fabrizi de Biani, F. Voltammetric Techniques. In Inorganic Electrochemistry: Theory, Practice, and Application; The Royal Society of Chemistry: Cambridge, UK, 2012; pp 42-109.

Kang, P.; Cheng, C.; Chen, Z.; Schauer, C. K.; Meyer, T. J.; Brookhart, M. Selective Electrocatalytic Reduction of $\mathrm{CO}_{2}$ To Formate by Water-Stable Iridium Dihydride Pincer Complexes. J. Am. Chem. Soc. 2012, 134, 5500-5503.

Costentin, C.; Drouet, S.; Passard, G.; Robert, M.; Savéant, J.-M. Proton-Coupled Electron Transfer Cleavage of Heavy-Atom Bonds in Electrocatalytic Processes. Cleavage of a $\mathrm{C}-\mathrm{O}$ Bond in the Catalyzed Electrochemical Reduction of $\mathrm{CO}_{2} . \mathrm{J} . \mathrm{Am}$. Chem. Soc. 2013, 135, 9023-9031.

Costentin, C.; Drouet, S.; Robert, M.; Saveant, J. M. A Local Proton Source Enhances $\mathrm{CO}_{2}$ Electroreduction to $\mathrm{CO}$ by a Molecular Fe Catalyst. Science 2012, 338, 90-94. Costentin, C.; Robert, M.; Savéant, J.-M.; Tatin, A. Efficient and Selective Molecular Catalyst for the $\mathrm{CO}_{2}$-To-CO Electrochemical Conversion in Water. Proc. Natl. Acad. Sci. U.S.A. 2015, 112, 6882-6886.

Costentin, C.; Passard, G.; Robert, M.; Saveant, J. M. Ultraefficient Homogeneous Catalyst for the $\mathrm{CO}_{2}$-To-CO Electrochemical Conversion. Proc. Natl. Acad. Sci. U.S.A. 2014, 111, 14990-14994.

Azcarate, I.; Costentin, C.; Robert, M.; Savéant, J.-M. Through-Space Charge Interaction Substituent Effects in Molecular Catalysis Leading to the Design of the Most Efficient Catalyst of $\mathrm{CO}_{2}$-To-CO Electrochemical Conversion. J. Am. Chem. Soc. 2016, 138, 16639-16644.

Pun, S.-N.; Chung, W.-H.; Lam, K.-M.; Guo, P.; Chan, P.-H.; Wong, K.-Y.; Che, C.M.; Chen, T.-Y.; Peng, S.-M. Iron(I) Complexes of 2,9-Bis(2-Hydroxyphenyl)-1,10Phenanthroline $\left(\mathrm{H}_{2}\right.$ Dophen $)$ as Electrocatalysts for Carbon Dioxide Reduction. X-Ray Crystal Structures of $[\mathrm{Fe}(\text { Dophen }) \mathrm{Cl}]_{2} \cdot 2 \mathrm{HCON}\left(\mathrm{CH}_{3}\right)_{2}$ And $[\mathrm{Fe}($ Dophen $)(\mathrm{N}-$ $\left.\mathrm{MeIm})_{2}\right]_{\mathrm{ClO}_{4}}(\mathrm{~N}-\mathrm{MeIm}=1$-Methylimidazole $)$. J. Chem. Soc., Dalton Trans. 2002, 291, 575-579.

Chen, L.; Guo, Z.; Wei, X.-G.; Gallenkamp, C.; Bonin, J.; Anxolabéhère-Mallart, E.; Lau, K.-C.; Lau, T.-C.; Robert, M. Molecular Catalysis of the Electrochemical and Photochemical Reduction of $\mathrm{CO}_{2}$ With Earth-Abundant Metal Complexes. Selective Production of $\mathrm{CO}$ vs HCOOH by Switching of the Metal Center. J. Am. Chem. Soc. 2015, 137, 10918-10921.

Taheri, A.; Thompson, E. J.; Fettinger, J. C.; Berben, L. A. An Iron Electrocatalyst for Selective Reduction of $\mathrm{CO}_{2}$ To Formate in Water: Including Thermochemical Insights. ACS Catal. 2015, 5, 7140-7151.

Sawyer, D. T.; Sobkowiak, A.; Roberts, J. L. Electrochemistry for Chemists, 2nd ed.; John Wiley and Sons, Inc., 1995.

Connelly, N. G.; Geiger, W. E. Chemical Redox Agents for Organometallic Chemistry. 
Chem. Rev. 1996, 96, 877-910.

(15) Costentin, C.; Savéant, J.-M. Multielectron, Multistep Molecular Catalysis of Electrochemical Reactions: Benchmarking of Homogeneous Catalysts.

ChemElectroChem 2014, 1, 1226-1236. 